\title{
TRANSPORTING THE EUROPEAN SOCIAL PARTNERSHIP MODEL TO AUSTRALIA
}

\section{Paul Gollan}

Associate Fellow

Department of Industrial Relations

London School of Economics

\section{Glenn Patmore}

Senior Lecturer

Faculty of Law

The University of Melbourne

Centre for Corporate Law and Securities Regulation and

Centre for Employment and Labour Relations Law

The University of Melbourne 
Published in Melbourne by the Centre for Corporate Law and Securities Regulation and the Centre for Employment and Labour Relations Law

\section{Centre for Corporate Law and Securities Regulation}

Faculty of Law

The University of Melbourne

Victoria

Australia 3010

Phone: + 61383445281

Fax: +61383445285

Email: cclsr@law.unimelb.edu.au

Website: http://cclsr.law.unimelb.edu.au

\section{Centre for Employment and Labour Relations Law}

Faculty of Law

The University of Melbourne

Victoria

Australia 3010

Phone: + 61383448924

Fax: + 61383444623

Email: celrl@law.unimelb.edu.au

Website: http://www.law.unimelb.edu.au/celrl

Gollan, Paul and Patmore, Glenn

Transporting the European Social Model into Australia

(C) 2005 P Gollan and G Patmore

This publication is copyright. Except as permitted under the Copyright Act 1968 (Cth), no part of this publication may in any form or by any means (electronic, mechanical, microcopying, photocopying, recording or otherwise) be reproduced, stored in a retrieval system or transmitted without the specific written permission of the publisher. 


\section{Table of Contents}

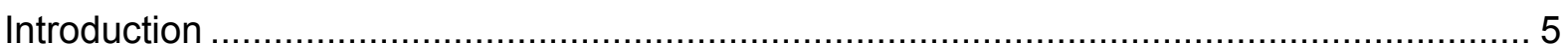

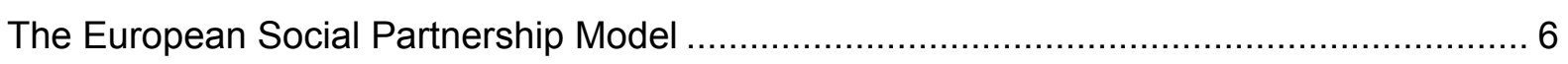

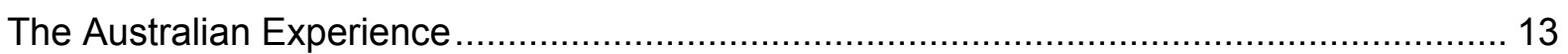

Court and tribunal decisions and employee participation ............................................ 13

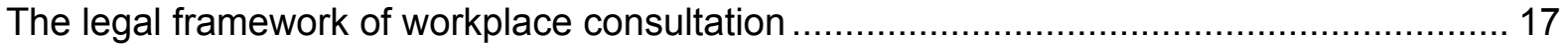

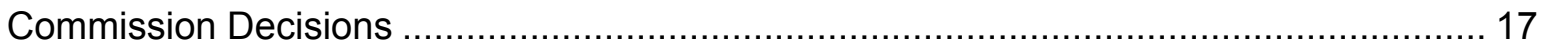

The legislative context - recent federal government approaches .................................... 20

Implementing a social partnership model of employee consultation in Australia .................. 26

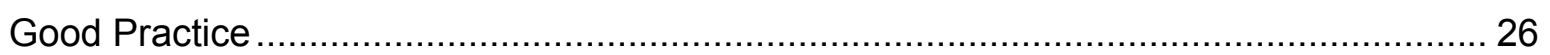

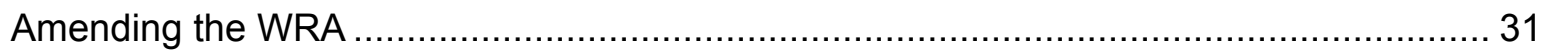

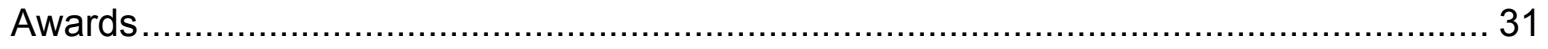

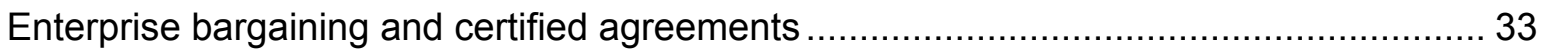

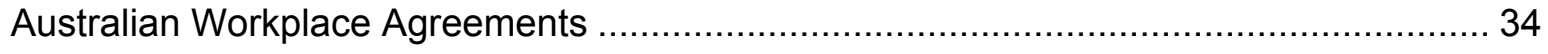

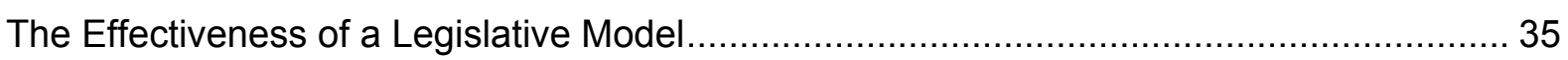

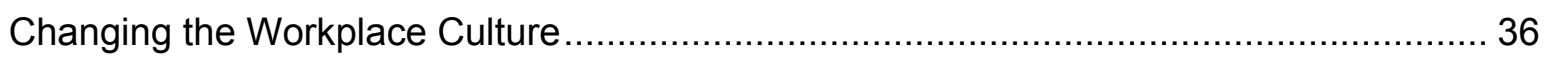

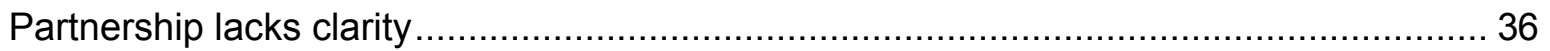

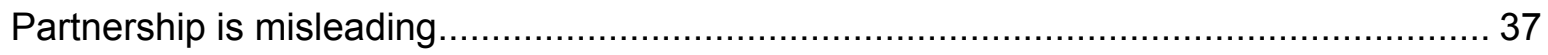

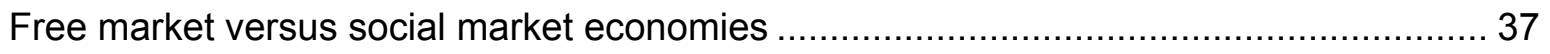

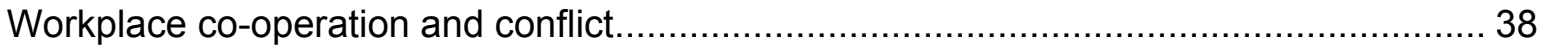

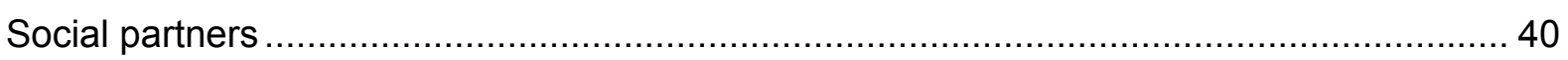

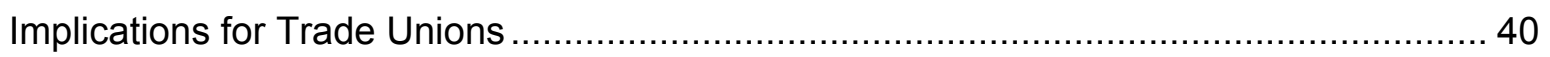

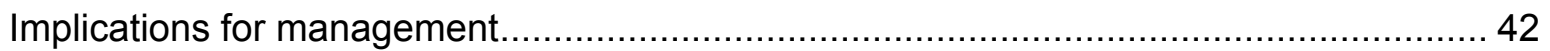

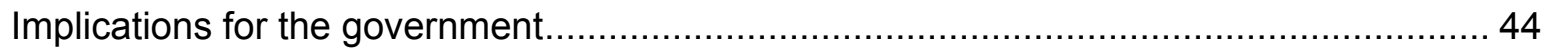

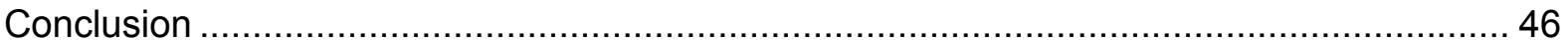

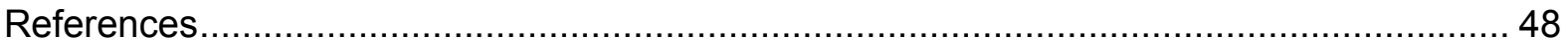




\title{
Transporting the European Social Partnership Model to Australia
}

\author{
By Paul J. Gollan and Glenn Patmore ${ }^{1}$
}

\section{Abstract}

There has been a long tradition of debate over workplace democracy in Australia. Yet, workplace democracy remains one of the great unfulfilled promises of Australian labour law. While the current focus on enterprise bargaining in the workplace might encourage us to think about new information and consultation mechanisms at work, there are no legislative provisions imminent. We argue that the voluntary approach of recent Australian governments has failed to create a generally available right to consultation at work. In this article we therefore consider how information and consultation procedures could be introduced into Australia, drawing upon the European social partnership model and the Australian experience with employee consultation mechanisms. In particular, the paper assesses employee consultation procedures in light of good workplace relations practices, examines how the Workplace Relations Act could be amended to incorporate a new model, and assesses its likely effectiveness in the current Australian industrial relations context.

\footnotetext{
${ }^{1}$ Forthcoming publication in the Journal of Industrial Relations. Paul J. Gollan is an Associate Fellow in the Department of Industrial Relations at the London School of Economics, email p.j.gollan@1se.ac.uk. Glenn Patmore is a Senior Lecturer at The Melbourne Law School, The University of Melbourne, g.patmore@law.unimelb.edu.au. The authors would like to thank Mr Ben Ferguson, Mr Samuel Koehne and Ms Joyce Chia for their invaluable research assistance in the preparation of this article. Very special thanks must also be given to Ms Shelley Marshall who read a draft of this paper and Ms Anna Chapman who read an extract of the paper. The authors thank them for their very thoughtful comments. All errors are the authors' own.
} 


\section{Introduction}

There has been a long tradition of debate over workplace democracy in Australia. Its continual, phoenix-like re-emergence over the last 30 years in government and academic literature testifies to the power of the idea and its capacity to capture the collective imagination. Equally, its fading from the political agenda is strong evidence of the tenacity and vitality of those powerful forces that stand against it. In our view, workplace democracy remains one of the great unfulfilled promises of Australian labour law.

The terms 'workplace democracy' and 'employee participation' are often used synonymously. When we use these terms, we mean the rights and entitlements of employees to influence decisions affecting their working lives. From this perspective, there are a variety of legal forms of employee participation mechanisms in existence in Australia today. These include collective bargaining over wages and conditions, the existence of occupational health and safety schemes under State legislation, ${ }^{2}$ and several limited legislative and contractual consultative entitlements relating to redundancy. ${ }^{3}$ Unlike citizens in many other Western democracies, under Commonwealth law Australians do not have a general right to be consulted and informed in their workplaces (Combet, 2001).

This article is based on a consideration of the absence of such rights in the Australian context. As a means of promoting employee representation, the article focuses on a new framework for employee information and consultation. (See also Gollan, 2002; Gollan, Markey and Ross, 2001; Patmore, 1999; Patmore, 2001). We look to recent developments in Europe, which are underpinned by a model of 'social partnership' and how such a model could be incorporated in Australian labour law. The significance of the social partnership model is that it moves beyond a very narrow conception of the employment relationship as a function of the labour market, towards a consideration of work in a broad social context. Under this model, employees and employers possess important social rights and responsibilities. Most importantly, some of these social rights have been enshrined in European law. ${ }^{4}$

\footnotetext{
${ }^{2}$ See for instance, Industrial Relations Act 1991 (NSW).

${ }^{3}$ See for instance, Workplace Relations Act 1996 (Cth) (WRA), Part VIA, Division 3, Subdivisions D and E.

${ }^{4}$ While many authors have considered the prospects of adoption in Australia of European Works Councils, this article is distinctive because of its exploration of the European social partnership model as a basis for introducing new information and consultation procedures in Australia. Our focus on the European social partnership model means that not all aspects of the introduction of works councils into Australia will be
} 
Our article explores how the European social partnership model might be transported to Australia and provides an introduction within this context. The article is informed by the social, political and economic context and is therefore interdisciplinary, drawing upon the disciplines of labour law and industrial relations. Our purpose is to outline the potential possibilities and limitations of the social partnership approach in the Australian industrial relations context, rather than focus on an examination of the legal technicalities or the compliance mechanisms required under the European Directives.

As a means to achieve this, we first briefly review the European social partnership model. Europe has a long history of utilising employee consultation mechanisms and in this section we explore the principles and procedures of two notable Directives from the European Council relating to employee participation, the European Works Council Directive (EWCD) and National Directive establishing a general framework for informing and consulting employees within member states (NDIC).

In the second part of the paper, we review the Australian experience of employee representation. We assess judicial and tribunal decisions in Australia that have supported the development of schemes of workplace democracy. We also look at recent federal government approaches towards the provision of employee consultation and information.

Thirdly, we outline some of the challenges in implementing a social partnership model of employee consultation in the Australian context. In this part we outline the kind of social partnership arrangements that might be adopted, possible amendments to the Workplace Relations Act 1996 (Cth) (WRA) and the likely success of such a legislative model in the Australian context. Finally we draw some conclusions from the preceding review.

\section{The European Social Partnership Model}

Experience in Europe suggests that the social partnership model has been a particularly effective means of incorporating employee democracy into law. By social partnership we mean the role that 'social dialogue' plays in both developing and maintaining statutory forms

discussed. The paper also makes a contribution to the literature in that it labels the model explaining its operation drawing upon EU directives and accompanying explanatory documents. 
of employee participation. According to the social partnership model, participants in a business enterprise have both an economic and a social function. In Europe, the term 'social partner' refers to various actors such as government, employers, employees and union representatives (Flynn, 1999). Accordingly, the European Commission consults with key social partners prior to issuing European Union Directives ${ }^{5}$, which are forms of law that apply to all member states. To illustrate the operation of EU Directives, brief references will also be made to relevant instances where the UK has implemented regulations.

The social partnership model is well illustrated by the European Works Councils Directive (EWCD, 1994 \& 1997; The Transnational Information and Consultation of Employees Regulations 1999 (TI\&CE Regs 1999) which was issued by the European Parliament in the mid to late 1990s. Works Councils (EWCs) have been prevalent in Europe for many years and are typically a committee of employees that is consulted by management over important workplace decisions. The Directive applies to large transnational enterprises, with at least 1000 EU employees, and two businesses of at least 150 people in different Member States (EWC, 1997: art. 2(1)(a)).

The foundations for the social partnership model can be found in the aims of the EWCD. Some of its key aims are:

- to foster and improve workers' fundamental social rights to information, consultation and participation; and

- to promote dialogue between management and labour to harmonise concentrations, cross-border mergers, takeovers and joint ventures directed towards the transnationalisation of undertakings ( $E W C D, 1994$ : Explanatory Memorandum, recitals, art. 1(1)).

Clearly, these objectives are simultaneously social, economic and cultural, and they address some problems particular to the process of European integration. In essence, the implementation of the $E W C D$ has created a new form of social partnership. The Directive adopted a two-stage approach (Barnard, 1999: 15) to creating partnerships at work. The first stage encourages voluntary negotiations to satisfy the Directive (EWCD, 1994: art. 5;

\footnotetext{
${ }^{5}$ Agreement on Social Policy attached to the Protocol (No 14) on Social Policy annexed to the Treaty establishing the European Community.
} 
Barnard, 1999: 15) either by allowing existing EWCs to continue to operate, creating new EWCs, or fashioning alternative arrangements for satisfying the Directive's requirements (EWCD, 1994: arts 6, 12-13; Bellace, 1997: 351). By April 1999, almost 600 corporations which are potentially covered by the law had established EWCs by means of company agreements, covering one-third of all undertakings (and about 40 per cent of employees) (Conference on the Practical Application of the European Works Council Directive, 1999). There has been a steady increase in the numbers of EWCs in recent years. By November 2002, some 750 EWCs were in existence (EWC, 2002: art 3).

The second stage imposed mandatory requirements on companies to comply with the Directive. Where no agreement can be reached between employers and employees, 'subsidiary' provisions apply (EWCD, 1994: art. 7; Barnard, 1999: 15). Although these mandatory default provisions are fairly modest (Barnard, 1999: 15), it is significant because they require the establishment of a designated model of a works council.

The subsidiary provisions (contained in the annex) prescribe a way forward, as well as a structure for EWCs. EWCs comprise a committee of between three and thirty employees. As a means to satisfy the social objectives of the Directive, the committee is required to consult with management about major issues affecting their company, including:

- the 'structure, economic and financial situation' of the company;

- the 'probable development of the business'; and

- the 'situation and probable trend of employment', mergers, cut-backs and closures of undertakings, and collective redundancies (EWC, 1994; EWCD, 1994: annex 2).

The mandatory requirements also create a legal mandate for workplace democracy which could be applied to the Australian context. However, different features of the EWCD both raise doubts and reinforce its democratising effect. EWCs can be composed either of elected or appointed representatives (EWCD, 1994: Annex). In failing to guarantee that EWCs have a clear democratic mandate, the Directive potentially limits its legitimacy and efficacy. Without elections, the EWCs legitimacy is derived from its legal mandate in conjunction with its partnership role and the appointment of employees. Importantly, the legitimacy of staff representatives may be enhanced if they are union members - unions being the traditional 
representatives of employees. To ensure employees have an input in the workplace, the Directive protects security of tenure, guarantees their pay and deals with the withholding of information by central management ( $E W C D, 1994$ : art. 10). Nonetheless, the $E W C D$ protects confidential information ( $E W C D, 1994$ : art. 8). While this restriction is important in maintaining a competitive position for undertakings, potentially it may restrict information and consultation between employees and their Works Council representatives. Lastly, both the EWC and management are under an obligation to work in a spirit of cooperation (EWC, 1994; $E W C D, 1994:$ art. 9). This cooperative spirit is regarded as critical to creating a climate of trust, a fundamental pre-requisite for developing and maintaining partnership at work.

While unions are recognised as social partners in the EWC framework, their role is not explicitly defined by the Directive. Rather the $E W C D$ leaves several important matters to be stipulated by national legislation (Muller-Jentsch, 1995). These matters include:

- whether representatives are elected or appointed;

- the EWCs' 'ability to engage in industrial action';

- the EWCs' 'ability to engage in wage bargaining, and the form of protection of wages and conditions of employees' representatives'; and

- the minimum requirements of employer 'consultation with EWCs and the remedies available if employers fail to consult adequately with EWCs' (Bellace, 1997: 357; EWCD, 1994: art. 9).

These matters have been left to national governments so that EWCs can be integrated into individual national systems of industrial relations. This is because, under European Law, the national government is authorised to regulate the conduct of unions and employers within their own industrial relations framework (Collins, 2003: 7-8).

In addition to the EWC initiatives, features of social partnership can also be found in another EU Directive, the NDIC. This Directive establishes a general framework for improving participation rights of employees in large nationally-based enterprises. The directive was proposed in November 1998 and was adopted and came into force in March 2002 (Directive No.2002/14/EC). The UK government responded promptly to the new Directive, issuing 
regulations which came into effect on 6 April 2005 (The Information and Consultation of Employees Regulations 2004 (I\&CER)).

Potentially, this Directive is more far reaching than the earlier EWC Directive, covering a broader range of issues and establishing a more thorough legally-based consultation process (Gospel and Willman, 2003). This Directive will eventually apply to all undertakings or businesses with more than 50 employees in all member states (NDIC, 2002: art 3(1)(a) \& (b)). ${ }^{6}$ Notably, it is estimated that the NDIC could cover about 60 per cent of employees within the EU (Burns, 2000). In the UK, it is estimated that three quarters of the entire labour force could be covered after full implementation of the Directive in five years (Gospel and Willman, 2003).

The Directive's foundation in the social partnership philosophy is evident in the preamble to the $N D I C{ }^{7}$ Some key aims mentioned in the preamble are (NDIC, 2002):

- to promote social dialogue between management and labour;

- to strengthen dialogue and promote mutual trust within undertakings;

- to increase employee availability to undertake measures and activities to increase their employability, promote employee involvement in the operation of the future of the undertaking and increase its competitiveness; and

- to ensure that all citizens benefit from economic development

Clearly, the purposes of the NDIC are both economic and social. The list of topics to be discussed by employers and employees are:

- the future development of the enterprise's activities and its economic situation (NDIC, 2002: $\operatorname{art} 4(2)(a))$

- employment, particularly where there is a threat to employment within the business $(N D I C, 2002:$ art 4(2)(b)), and

\footnotetext{
${ }^{6}$ As part of the agreement with the UK, the Directive is being introduced in phases: firms with more than 150 employees have until 6 April 2005 to set up information and consultation procedures; firms with more than 100 employees have until 6 April 2007; and those firms with more than 50 employees will be included under the Directive from 6 April 2008.

${ }^{7}$ The preamble is a statement which promotes the general policy of the introduction of information and consultation procedures in every large national business throughout Europe.
} 
- issues likely to lead to substantial changes in work organisation or contractual relations, especially issues directly affecting job security such as collective redundancies and business transfers (NDIC, 2002: art 4(2)(c)).

The topics of firm performance, continuance of employment and job security have both economic and social implications. Given the scope of the preamble, new topics not yet included may be added to the list, such as training, the development of human capital and equal opportunities (Collins, 2003a).

The new Directive allows for flexible partnership arrangements. Much like the earlier EWCD for large enterprises, the Directive permits employers and employees to negotiate implementation procedures for information and consultation (NDIC, 2002: art. 5). If no agreement can be reached within a required period of time, then an employer must adopt the statutorily mandated information and consultation committee, which is in effect a works council. (I\&CER: r. 18(1)(b)). However, the employer and the committee have the flexibility to change the structure at a later date (I\&CER: r. 18(2)). Unlike the $E W C D$, the Directive does not therefore mandate the establishment of a Works Council, but leaves open the kinds of arrangements that might be implemented or altered.

Remedies are available where an employer fails to establish information and consultation procedures and to settle disputes about their operation. The NDIC states that sanctions for failing to comply with the obligations contained in the Directive should be 'effective, proportionate, and dissuasive' (NDIC, 2002: art. 8(2)). In the UK, the regulations state that failure to comply will incur a fine of up to $£ 75,000$ (I\&CER: rr. 21(2), 32(2), (4). See generally, I\&CER: Part IV).

The NDIC provisions regarding employee and employer protection mirror those of the $E W C D$, raising similar issues of strengthening and weakening the democratic functions of representatives. Accordingly, employees' representatives have adequate 'protection and guarantees' to enable them to perform their duties including pay, tenure and time off (NDIC, 2002: art 7). The NDIC protects confidential information (NDIC, 2002: art 6). The Directive imposes an obligation of co-operation on those arranging or implementing a negotiated agreement or when implementing the standard procedures (NDIC, 2002: art 1(3)). It could be 
similarly argued that such an obligation is a prerequisite to the establishment of mutual trust and obligations.

Significantly, the NDIC leaves it up to member states to decide the role for trade unions within the social partnership framework, with trade unions having a central role in many European countries and a less important role in the UK. Furthermore, the UK regulations are not linked to collective bargaining, nor is trade union involvement mandated by the scheme (Collins, 2003a).

While the $E W C D$ focuses on the harmonisation of transnational arrangements within the internal European market, the NDIC focuses on the challenges presented by changing employment arrangements and the competitive pressures of globalisation. The philosophy underpinning the NDIC is to move organisations into a new approach based on high skill, trust, quality and performance and the involvement of employees in workplace decision making, thus necessitating new thinking and practice ${ }^{8}$. The significance of this social partnership model for managers in the UK, is that they must engage in a new form of dialogue with employees and/or trade unions.

These EU initiatives are meant to complement other policies of the European Commission including moving to lifelong learning; adaptation of social legislation and of tax systems based on a normal working life; new means of remuneration; working time; and equal opportunities (European Commission, 1998).

It can be concluded that overall the European Commission's aim is to forge the social partnership agenda and develop a framework for the modernisation of the organisation of work. As the European Commission has suggested, this modernisation could be achieved through the creation and support for joint understanding, through joint declarations, or through binding legal initiatives (European Commission, 1998).

\footnotetext{
${ }^{8}$ It could be argued that high skill produces the capacity and capability for individuals and organisations, trust provides the means and process to access that capacity, and quality and performance are its outcomes underpinned by greater employee involvement in the decision-making arrangements (Gollan, 2005). ${ }^{9}$ Importantly, speaking after the adoption of the NDIC proposal, the then Employment and Social Affairs Commissioner, Pádraig Flynn, stated: "This is an important day for social Europe, as, after a long phase of preparation and consultation, we are presenting an important tool in the search for greater adaptability in the workforce. The Commission's proposal provides a framework within which the Member States and the social partners can ensure an effective and balanced involvement of workers in a more positive and flexible approach to reorganisation and change, especially the modernisation of work organisation."
} 


\section{The Australian Experience}

EU employee information and consultation and national legislation which has been enacted in many European countries (Gardner and Palmer, 1997: 344) has not been matched in Australian national or State legislation. Yet, some participatory decision-making processes have been recognised in court and tribunal decisions in our industrial relations system. We now review the approach of the courts and tribunals to the development of participatory decision-making processes, as well as assessing recent federal government policies in relation to legislative reforms incorporating improved employee consultation and information.

\section{Court and tribunal decisions and employee participation}

Some participatory decision-making processes have existed in Australia's industrial relations system, fostered by court and tribunal decisions. These schemes of employee participation represent the antecedent for the development of a possible partnership model, although their emergence was subject to constitutional and legal challenges to their validity.

\section{Constitutional validity}

The creation of the consultation and information schemes by the federal parliament is subject to the Australian Constitution. The Australian Constitution provides that the federal parliament can only make laws with respect to a list of particular subject matters, or what is sometimes referred to as 'head of power'. If a Commonwealth law does not fall within a head of power the High Court must hold that the law is invalid, which means it is rendered inoperative.

The Parliament does not possess a single head of power that would enable it to legislate generally on the subject of industrial relations. However, two key grants of power have been relied upon by the federal parliament to create schemes of employee participation: namely, 
the labour power and the corporations power ${ }^{10}$.

The federal corporations power in section 51(xx) of the Australian Constitution permits the Parliament to pass laws with respect to 'foreign, trading or financial corporations formed within the limits of the Commonwealth'. The corporations power was relied upon by the Keating Government to introduce non-unionised Enterprise Flexibility Agreements (EFAs) requiring an employee committee to facilitate and consult over the establishment of such agreements as well as to introduce workplace consultative committees (Mitchell, Naugthon and Sorenson, 1997: 203-4) a development discussed later in this article. The corporation's power also sustained the shift to enterprise bargaining, and could provide a basis for establishing European-style information and consultation schemes in Australia.

This expansive view of the corporations power is supported by the majority judgement of the High Court in Victoria v Commonwealth (Industrial Relations Act Case). Their Honours seem to have accepted that the federal parliament can regulate the employment conditions of a corporation named in section 51(xx) of the Australian Constitution. Regulation of employment conditions is broad enough to include the creation of employee consultative committees in incorporated companies, which could provide a necessary forum for employee democracy to flourish.

The federal labour power provides another head of power to enact laws for the democratisation of work - one that has been more extensively relied upon than the corporations power. The federal labour power in section 51(xxxv) of the Australian Constitution permits the federal parliament to make laws with respect to the settlement and prevention of industrial disputes. It has been claimed that the federal labour power would not cover employee consultation, because consultation of employees is not a proper subject of an industrial dispute. Rather, it is argued that it is entirely a matter for management to determine (Creighton and Stewart, 2000: 77-8).

In Re Cram the High Court comprehensively rejected this view, maintaining that the

\footnotetext{
10 In this article we have only discussed those powers which have been relied upon by the federal Parliament to create schemes of employee participation. There are other potential powers that could be relied upon, including the taxation power, the trade and commerce power, and the territories' power or powers in other state jurisdictions. (For a comprehensive study of how these powers might be used to support schemes of employee participation see McCallum and Patmore, 2002).
} 
managerial prerogative:

[p]robably echoes in some respects what was received doctrine at an earlier time - that it was the prerogative of management to decide how a business enterprise should operate and whom it should employ, without the workforce having any stake in the making of such decisions ... Over the years that climate of opinion has changed quite radically ... No doubt our traditional system of industrial conciliation and arbitration has itself contributed to a growing recognition that management and labour have a mutual interest in many aspects of the operation of a business enterprise. (Re Cram: 125)

The High Court reinforced this view by broadly defining the meaning of an 'industrial matter'. This included management decisions that directly affect the employment relationship, for instance, levels of employment and modes of recruitment. It is hard to see any future High Court retreating from this evolutionary and commonsense interpretation of the labour power. The significance of this case is that it puts beyond doubt the fact that the award system established under the labour power may be relied upon by a federal parliament to introduce schemes of employee participation. We have reached the stage where employee participation schemes can validly be enacted under the labour or corporations powers. It is one thing to recognise the broad scope of the federal parliament's powers; another equally important consideration is an assessment of the development of legally mandated employee participation schemes in Australia.

\section{The conciliation and arbitration system ${ }^{11}$}

The initial vehicle for establishing the democratisation of work in Australia has been the centralised tribunal-based systems of compulsory State and federal conciliation and arbitration, which were established in order to settle industrial disputes. Throughout last century, these systems regulated much of the conduct of the participants in Australia's industrial relations. These systems still exist at the federal level and in all States of Australia $^{12}$. Respective federal and State Acts of Parliament provide for the establishment of

\footnotetext{
${ }^{11}$ This section draws partially from an Australian Centre for Industrial Relations Research and Training (ACIRRT) working paper by Gollan, P., Markey, R. and Ross, I. (2001) 'Additional forms of employee representation in Australia', Working Paper 64, University of Sydney.

${ }^{12}$ In Victoria, the Australian Industrial Relations Commission (AIRC) exercises limited arbitral powers with respect to most Victorian employees: see Part XV of the WRA. The Independent Report of the Victorian
} 
industrial tribunals, the registration and legal recognition of employer and employee associations (unions ${ }^{13}$ ), and detail the rights and obligations of the parties subject to some legislative limitations. The tribunals are empowered to handle industrial disputes and to set wages and conditions of employment embodied in awards. ${ }^{14}$

Historically, employer and employee associations together with the industrial tribunals have dominated the wage-setting and dispute-resolution processes. Employees have only been able to access this system through being represented by trade unions. However, in recent years union density and award coverage has declined dramatically. ${ }^{15}$ The traditional relationship between employer and employee associations has been and continues to be more as adversaries, in conflict with each other, than as partners co-operating together in making submissions to industrial tribunals.

Furthermore, until the 1980s, tribunals - supported by the courts - traditionally treated managerial prerogative as sacrosanct in areas outside a narrow perception of 'industrial issues' (essentially wages and hours). Issues such as technological and organisational change and issues associated with it, training, and the structure of the workforce, all of which would be the subject of consultation (and even co-determination) in European works councils, were thus effectively excluded from the jurisdiction of the Australian industrial relations system until the mid-1980s (Markey, 1987).

\footnotetext{
Industrial Relations Taskforce recommends the reestablishment of a limited form of State IR Tribunal for Victorian employees. See Part XV of the $W R A$ which provides for the Federal Commission to provide conciliation and arbitration in Victoria.

${ }^{13}$ In Australia the legal regulation of trade unions is essential to arbitration and conciliation and confers corporate status protection against discrimination, and security and protection against competing unions covering the same industry or occupation. The AIRC needs to be satisfied that 'the association is free from control by or improper influence from, an employer, or an association or organisation of employers' (WRA s 189 (aa)).

${ }^{14}$ An award is an order that is the product of a settlement of a dispute by an industrial tribunal made under the federal labour power. In some cases awards "apply to whole industries across the entire continent, in others they apply only to part of an industry in a particular State or region, or even to specific enterprises." (Creighton and Stewart, 2000: 122).

${ }^{15}$ It is estimated that Australian trade union membership has declined to around 24 per cent of the workforce by 2002, a decline in union membership from 45 per cent in 1986 (Australian Bureau of Statistics, 2002: 6310.0 Employee Earnings, Benefits and Trade Union Membership, Australia). According to ACIRRT 42 per cent of the workforce is covered by registered collective agreements and an additional 44 per cent of the workforce covered by awards and over-award arrangements (including unregistered agreements). About half of this group are covered by an award only. In addition, $14 \%$ of workers are covered by individual arrangements (only about $1.7 \%$ of the workforce is covered by Australian Workplace Agreements) (ACIRRT, 2003: http://www.acirrt.com/research/default.htm).
} 


\section{The legal framework of workplace consultation Commission Decisions}

During the 1980s, two dramatic changes occurred in the Australian system. Firstly, tribunals (supported by the High Court) broadened the scope of issues considered to be suitable for consultation (Markey, 1987). These tribunals also spelt out in quite some detail the methods for participation in workplace decision making. They have also endeavoured over time to give practical guidance on the conduct of workplace consultation.

The Australian Conciliation and Arbitration Commission (now the Australian Industrial Relations Commission (AIRC)) initially created an entitlement to employee participation in response to the Australian Council of Trade Union's (ACTU) 1984 Termination, Change and Redundancy Test Case (TCR Case 1984) and the judgment in the following year (TCR Case 1985). The ACTU sought improvements in employee job security by establishing obligations on employers to, amongst other things, consult with employees and provide information about changes to work methods (TCR Case 1984: 37), the introduction of new technology (TCR Case 1984: 35) and proposed redundancies (TCR Case 1984: 37; see also Appendix B, TCR Case 1984)

Responding to the ACTU's claim, the Commission inserted provisions into awards requiring employers 'to consult with employees and their representatives as soon as a firm decision had been taken about major changes in production, program, organisation, structure or technology which are likely to have a significant effect on employees'. Employers had to provide in writing 'relevant' information (TCR Case 1984: 52) including an explanation of the nature of the proposed changes and their expected effect on employees. But employers were not required to disclose confidential information. (TCR Case 1984: 53)

In addition, the Commission inserted a provision requiring an employer to notify and consult with employees or their union representatives where it had decided to make employees redundant. (TCR Case 1984: 64) The Commission adopted a broad and flexible definition of redundancy (TCR Case 1984: 61-62). It required employers to provide 'relevant' information in writing including "the reasons for the proposed terminations, the number and categories of employees likely to be affected, the number of workers normally employed and the period over which the terminations are likely to be carried out" (TCR Case 1984: 64). 
Employers were not required to "disclose confidential information the disclosure of which would be inimical to its interests" (TCR Case 1984: 64).

The Commission observed that procedures 'for notification, consultation and information have generally been settled by agreement and negotiation' and was of the view that such matters generally do 'not lend themselves to effective legislation or award prescription'. Nonetheless, the Commission decided to include an award provision requiring employers to consult with employees regarding organisational change (TCR Case 1984: 52) and redundancies (TCR Case 1984: 64). While the Commission did not explicitly justify the inclusion of a provision dealing with organisational change, it did provide the rationale for inclusion of a consultation provision in relation to redundancy. The Commission said: "it is of fundamental importance to involve employees and their representatives in the problems of redundancy as soon as a firm decision has been taken that retrenchments may be necessary." Presumably this was to ensure that the interests of employees are taken into account when decisions are made (TCR Case 1984: 63).

Several comments in the judgment are significant, because they explore the limits of legal regulation and effective workplace participation. These provisions were seen as effective because they created basic procedures for information and notice, and simply tried to bring the parties concerned together in order to discuss the manner in which organisational change and redundancies might be managed (TCR Case 1984: 54).

Some perceived limits to the reach of this form of legal regulation were also expressed in the case. It was argued that the procedures were not intended to direct an employer as to what they should decide, but was meant to inform employees and to allow them to discuss major changes. Rather, consultation on matters such as job requirements, training, job security, working hours, monitoring of changes and the problems of redundancy were intended to minimise the potential for conflict which exists when such changes are introduced. Reduction of industrial disputes not only provides a practical rationale for consultative procedures. It also opens up the possibility for developing a form of partnership relationship, and fulfils the constitutional requirement that the Commission must endeavour to prevent or settle industrial disputes under the labour power of the Australian Constitution (TCR Case 1984: 51-3). The TCR Case 1984 \& 85 established rights for employee notice and information, significantly contributing to the necessary conditions for employee participation. However, it is critical to 
realise that it did not provide a forum or structure by which the consultation would take place (Combet, 2001).

The AIRC's consideration of the subject of consultation changed from examination of technological change and redundancy to the promotion of efficiency and productivity in Australian workplaces in the 1980s. This was accompanied by a second shift in the $80 \mathrm{~s}$, the decentralisation of the industrial relations system which emerged under the Commission's wage fixing principles. As part of this process, the AIRC required enterprises to establish appropriate mechanisms for consultation and negotiation on matters affecting the organisation's efficiency and productivity, when it adopted the 'structural efficiency principle' relating to award restructuring in 1988 (Dabscheck, 1995: 30-33, 51-63). The leading decision was the 1991 Wage Fixing Principles (National Wage Case 1991), which made wage increases subject to awards requiring enterprises to establish a consultative mechanism with their employees on matters affecting efficiency and productivity (National Wage Case 1991: 48) ${ }^{16}$. Significantly, this time the Commission combined the topics of discussion with a forum for negotiations.

The Commission saw consultative forums as desirable, because they provided a mechanism to focus the attention of the parties on structural changes at the workplace level (National Wage Case 1991: 49). Furthermore, the forum was intended to provide an 'educative process' for management and unions on how to negotiate at the workplace. The topics to be discussed were meant to provide benefits for both employers and employees. The principles were intended to create measures to meet the competitive requirements of industry and measures to provide workers with more varied, fulfilling and better paid jobs (National Wage Case 1991: 64). The Commission's decision was effective in that subsequently many awards 'contained provision for consultative committees or some other form of consultative mechanism' (Combet, 2001). The spread of joint consultative committees (JCCs) in Australian firms dates from this time.

Most importantly, by introducing these new consultative mechanisms the Commission tried to promote a co-operative model involving government, unions, employers, and tribunals. However, the decision of the Commission was highly contentious. This was because it

\footnotetext{
${ }^{16}$ The wage fixing function of the Commission consists of considering an application to vary the rates of pay set out in a number of key awards to ensure a "fair and reasonable" or "basic" wage (Creighton and Stewart, 2000: 41-2).
} 
introduced these consultative mechanisms as an alternative to the proposal advanced by the ACTU and the Federal Government that the Commission introduce a new system of wage increases based on enterprise bargaining. The Commission's suggestions that the parties were not sufficiently 'mature' nor competent to negotiate at workplace level were not appreciated. The government responded by introducing legislation which began the shift to wage increases being determined by enterprise bargaining rather than through the award system (Industrial Relations Act 1988 (Cth)). The reform process carried out by both the Labor and Liberal governments gradually diminished the Commission's power to provide for national wage increases. Ironically, while the Commission in the 1991 case laid the foundation for cooperative, possibly partnership-type relationships at the workplace, it undermined a cooperative partnership-type relationship between itself and the ACTU and the government.

\section{The legislative context - recent federal government approaches}

Australian governments have typically adopted a voluntarist approach to workplace democracy and employee consultation and participation. They have left matters about employee information and consultation to be dealt with by employers and employees, preferring not to invoke any form of legislative mandate (Mitchell, Naughton and Sorensen, 1997: 197). The notable exception to this rule came from the Keating Government in 1994 when it introduced some fairly modest legislative provisions relating to information and consultation. We will now move to assess the approach of the Hawke, Keating and Howard Governments in this area.

The Hawke Government through the Accord process created a corporatist model of partnership. Although the initial Accord did not mention the word partnership, it did create an agreement between two political actors, the ACTU and the Labor party opposition. The Accord provided an agreement for consultation with employees (via their representatives) on a vast range of matters, including prices and incomes. The partnership idea was reinforced by the Hawke Government's conception of industrial democracy as encompassing participation by employees and their representatives at the national, industry and enterprise levels (Department of Employment and Industrial Relations (DEIR), 1986: 23).

While the idea of partnership at the workplace level was never really implemented, the 
possibility of developing industrial democracy and employee participation was considered by the Hawke Government. In 1984, the DEIR held a conference on Industrial Democracy. The result was a policy discussion paper: Industrial Democracy and Employee Participation (DEIR, 1986; Davis and Lansbury, 1999). The purpose of the paper was to explore how democracy could be extended from Parliament to the workplace. Although there was recognition of the democratising effect and the 'social justice and equity' (DEIR, 1986: 34) aspects of workplace participation, the discussion remained underdeveloped. Expanded consideration could have been given to the way in which employee participation in decisionmaking can affect not only a person's economic status, but might also contribute to their personal development, enhance civic culture, or broaden social dialogue. Instead, the paper provided a blueprint for reform which emphasised the economic benefits of employee participation. The paper was premised on three fundamental principles:

- Industrial democracy, achieved through greater participation by employees and their representatives, is a desirable objective;

- Widespread participation will not occur spontaneously; and

- No single or simple model should be imposed [through legislation].' (DEIR, 1986: 11, $158)$.

The discussion paper was favourably disposed towards potential legislation that outlined basic rights and principles for information and consultation of employees, but left it to organisations themselves to create appropriate practices (DEIR, 1986: 11-2,158; Davis and Lansbury, 1999: 5). As Mitchell, Naughton and Sorensen explain, in the final analysis the Hawke Government preferred to 'seek the views of all interested parties in an endeavour to find the most appropriate ways of developing practices, or building on practices that were already underway, at the local level' (Mitchell, Naughton and Sorensen, 1997: 199). The result was that implementation of industrial democracy and employee participation was put on the back burner of the government's agenda.

In the early 1990s, the issue of employee involvement surfaced again with the shift of Australia's industrial relations system to enterprise bargaining. This form of bargaining necessitated consultative arrangements in the enterprise bargaining process itself. For instance, the need to protect employees required that they be consulted about the terms of an 
agreement before it was approved or certified (Mitchell, Naughton and Sorensen, 1997: 2034). Underlying the government's approach was a commitment to consultation as a means of providing sustainable economic reform. (Cook,1992: 2518; Brown, 1992: 3794). The Government promoted enterprise bargaining that encouraged 'an effective partnership at work and a highly skilled, adaptable and committed workforce' (Sherry, 1993: 3580).

Nationally, new consultation requirements were introduced in 1993 as part of the Commonwealth Industrial Relations Reform Act 1993 (the Reform Act). In particular, the provisions relating to non-union agreements or 'EFAs' stated that for an agreement to be approved it was necessary that during the negotiations 'reasonable steps' had been taken to 'consult' and 'inform' employees about the agreement and its terms. In addition, these terms needed to be 'explained' and employees 'advised' before the agreement was approved (Mitchell, Naughton and Sorensen, 1997: 203).

During this period the Keating Government enacted provisions establishing a mechanism for employee consultation and information that went beyond the terms of the enterprise bargaining process itself. Sections 170MC(1)(d) and 170NC(1)(f) of the Reform Act, made it a precondition for certification or approval that an agreement establish 'a process for the parties to the agreement to consult each other about matters involving changes to the organisation or performance of work in any place of work to which the agreement relates' unless 'the parties have agreed that it is not appropriate for an agreement to provide' such a process.

These provisions created a legislative direction to the parties to establish a broader scheme of ongoing consultation about workplace changes. However, this direction had several problems. The provisions were vague and failed to give any guidance on the frequency or make-up of this 'process' (Mitchell, Naughton and Sorensen, 1997: 204). In addition, these provisions did not prescribe the means (structure or processes) through which such consultation was to occur (Mitchell, Naughton and Sorensen, 1997: 203). Importantly, the Reform Act only required the establishment of a 'process' rather than a 'mechanism' or 'structure', and therefore did not necessarily envisage a permanent representative body. Nor did the legislation state how employees were to be represented in this process. 
It has been argued that this broader requirement was overlooked by the AIRC and by the vast majority of employers (Mitchell, Naughton and Sorensen, 1997: 208, 215-6). Despite these deficiencies, it has also been argued that the increase in indirect forms of employee participation in Australian Workplace Industrial Relations Surveys (AWIRS) from 19901995 has undoubtedly resulted from directives by industrial tribunals or legislative requirements related to enterprise bargaining. This is a positive sign, and suggests that legislatively mandated schemes can have an impact. However, in 1995 only a third of companies had joint consultative committees (Morehead, et. al, 1997: 193) and by European standards, this proportion is quite low.

In 1993, the Keating government introduced a further partnership initiative enacting provisions for consultation of employee representatives in relation to redundancies. These are now part of the $W R A$. The purpose of this amendment was to introduce a national scheme of entitlements with respect to redundancies and to strengthen the powers of the AIRC to protect workers' rights (Pragnell and Ronfeldt, 1994; Crichton \& Stewart, 2000: 311-312). Workers were therefore given new consultation rights where an employer proposes redundancies (WRA Subdivision $\mathrm{D}$ ) or where a decision has been made to make workers redundant (WRA Subdivision E).

Subdivision D (WRA ss 170FA-170FE) gives effect to Articles 12 and 13 of the Termination of Employment Convention. Under this division, the Commission has the power to make an order in relation to an employer's information and consultation obligations where it proposes redundancies. A termination that fails to comply with such an order is unlawful (WRA s 170CN).

Under Subdivision E (WRA ss 170GA-170GD), the Commission has power to make orders where an employer has decided to terminate 15 or more employees for economic or structural reasons and the Commission thinks that there has been inadequate consultation of the relevant trade union ( $W R A$ ss $170 \mathrm{GA}-170 \mathrm{~GB}$ ). In particular, the legislation explains that inadequate consultation means that an employer has failed, as soon as practicable, to do either of two things: 
(1) inform the trade union about the reasons for the terminations, the number and category of employees likely to be affected and the period over which the terminations will be carried out (WRA s 170GA(1)(a)); or

(2) give the trade union an opportunity to consult with the employer about measures to avert, minimise or mitigate the proposed terminations (WRA s 170GA(1)(b)).

In more recent years the Commission has clarified these obligations (WRA ss 170FA \& 170GA), explaining that:

- Consultation must take place when an in-principle decision is reached, and certainly before candidates for redundancy are identified (CPSU v Vodafone PR911257 (Vodafone): [28]; CPSU v Optus PR 912122 (Optus): [57]);

- Consultation once candidates have been selected is too late to allow effective contributions to the decision-making process, e.g. identifying relevant criteria and allowing for the possibility of voluntary redundancies (WRA s 170GA(1); (Vodafone): [28]);

- Consultation is not "perfunctory advice on what is about to happen" Vodafone: [25]; FSU v Commonwealth Bank PR921470 (Commonwealth Bank 2): 402);

- Consultation requires an informed decision (Vodafone: [25]; Optus: [38]; Commonwealth Bank 2: 402); and

- The process of consultation is not joint decision-making, nor is it a restriction on managerial prerogative (Vodafone: [25]; Optus: [52]; Commonwealth Bank 2: 402).

Where an employer fails to meet the statutory obligations, the AIRC has very considerable remedial powers. ${ }^{17}$ (FSU v Commonwealth Bank PR921049 (Commonwealth Bank 1): [22]). It can prohibit an employer from making employees redundant, require an employer to provide relevant information, and possibly issue a reinstatement order. (See Vodaphone: [13]; Optus: [63-66]; Commonwealth Bank 2: 402). ${ }^{18}$

Nevertheless it is important to recognise that the powers of the AIRC are still quite limited. The Commission can only exercise its powers upon the application of either an employee or a representative of a trade union under subdivisions $\mathrm{D}$ (WRA s 170FB) or $\mathrm{E}$ (WRA s 170GB).

\footnotetext{
${ }^{17}$ The AIRC may make whatever order it thinks appropriate, subject to public interest considerations, to put the employees or their unions in the same position as if there had been proper information and consultation (WRA $\mathrm{s}$ 170GA(2)).

${ }^{18}$ See ALHMWU v Rydges Australia Pty Ltd (2001) 50 AILR 4-471 (77).
} 
As Forsyth has pointed out, "the provisions do not really impose positive obligations on employers at all, but rather provide a mechanism whereby their failure to consult might be rectified 'after the event"' (Forsyth, 2002: 182) Vodafone: [7] ). Also, orders cannot be granted if an alternative remedy exists (WRA ss $170 \mathrm{FC} \& 170 \mathrm{GC})$.

While the Keating government's initiative certainly created a national scheme of redundancy entitlements, it is a scheme that only provides weak protection for most employees who are facing redundancies. Yet the Keating government's experiments with new forms of employee consultation has proved to be more pro-active than has hitherto occurred under the current Howard government.

The Howard Government was elected in 1996, and while it retained the very limited legislative consultative provisions in relation to redundancies (WRA Subdivisions D and E), the broader legislative provisions introduced by the Keating Government (Reform Act ss $170 \mathrm{MC}(1)(\mathrm{d})$ and $170 \mathrm{NC}(1)(\mathrm{f}))$ were removed. The Coalition Government opposes enforcement of employee participation by legislation (The Coalition Industrial Relations Policy, 1996). As Mitchell, Naughton and Sorensen explain:

[t]he government considered that these 'complex consultation provisions' were unnecessary because of the general requirement that certified agreements under the WRA would be required to be genuinely endorsed by a majority of employees at the workplace. The final position reached in the enactment of the legislation did not demand the same level of consultation and information sharing, or the establishment of a consultation process in the agreement itself (Mitchell, Naughton and Sorensen, 1997: 198).

Moreover, early in the Howard Government's first term it introduced a process which removed the consultation obligations in relation to organisational change inserted into awards. It embarked on a dramatic process of award simplification, limiting the number of award items to 20 allowable matters (WRA s 89A (1) - (3)). The consultation provisions in awards were deleted because they were not regarded as one of the 'allowable matters' (Re Award Simplification Provision, 1997; Crichton \& Stewart: 334). 
However, this was not the end of the matter. As we mentioned in our introduction, the terrain of employee consultation is a contested one and is ongoing. In 2004 the AIRC found a new way to re-insert consultation provisions over redundancies into awards (Redundancy Test Case 2004). The commission accepted that the list of allowable award matters (in particular WRA s 89A(2)(p) "dispute settling procedures") could include a redundancy dispute procedure. The provision in the Redundancy Test Case 2004 is different from the TCR decision in that it only applies to redundancies and not to technological change, but it was largely similar to the redundancy consultation provision in the TCR Test Case 1984.

It is significant that all of the industrial parties (the (Australian Council of Trade Unions), employer organisations and the government) agreed upon the redundancy dispute clause (Redundancy Test Case 2004; 224). This case suggests once a consultation procedure is introduced into the Australian industrial relations system, it may become widely accepted by all industrial parties. Quite positively, the case also demonstrates how information and consultation procedures - once introduced - may become accepted processes of contemporary Australian industrial relations. It is therefore timely that we consider how information and consultation processes could be improved and expanded in Australia.

\section{Implementing a social partnership model of employee consultation in Australia}

We now turn to consider how the social partnership model of employee consultation might operate in Australia. We first assess Australian information and consultation procedures in terms of good work practices and briefly describe the operation of the new proposed partnership arrangements. For these partnership arrangements to be introduced in Australia we argue that it will be necessary to amend the WRA. After outlining how the Act may be amended, we consider the likely success of such a model. We pay particular attention to how we can develop a coherent model that is technically feasible and practically possible in the Australian industrial relations system.

\section{Good Practice}

We now identify the kind of legislative criteria that promote good information and consultation practices. These are a synthesis drawn from the preceding argument, the 
historical development of partnership arrangements in Australia as well as the European experience. The $E W C D$ and $N D I C$ provide the minimum standards of good work practices for European companies. Legislative criteria for establishing good information and consultation procedures have also been tried and tested by courts and tribunals in Australia. Assessing the Australian approach against our proposed criteria below, we find it wanting. We argue for the development of a new legislative model and briefly sketch how it might affect work practices in Australia.

From the Australian experience, the following features can be identified:

- Relevant but not confidential information should be provided in writing to employee representatives ;

- Information should be provided when a firm decision is taken;

- Consultation should take place at an early stage in order to allow bona fide discussions;

- Consultation is providing employees with a bona fide opportunity to influence the decision maker;

- Consultation does not involve joint decision-making or interference with management's ultimate decision-making prerogative;

- There should be a forum or structure where the consultation would take place

- Topics for discussion should be specified; and

- Representative consultation should not be required in small organisations.

From the European experience, the following additional features can also be identified:

- There should be a statement of the economic and social purposes of the law;

- The composition of the committee should be specified;

- Representatives' security of tenure should be protected;

- The frequency of meetings should be specified; and

- The powers of the committee should be clearly described.

Our proposed features provide guidance for the drafting of a legislative model of information and consultation procedures, and can also act as a benchmark to assess Australian 
information and consultation procedures ${ }^{19}$. Australia has adopted processes for consultation of employees in relation to technological change, redundancy, productivity and efficiency in awards or legislation. Yet as we have shown there are deficiencies in these processes which have meant that they have fallen short of the good practice criteria.

The provision of consultation processes in Australia has also been affected by other serious problems which have undermined the development of good work practices. This includes the decline in union representation. Traditionally employees have been represented by trade unions in Australia but there has been a significant decline in union membership in recent years. Trade union membership declined from 51.1 per cent in 1976 to less than 25 per cent of the overall workforce in 2001 (Australian Bureau of Statistics (ABS), 2001), and declined further in 2003 to 23 per cent (with only 17.7 per cent in the private sector) (ABS, 2004). Thus, a substantial proportion of the workforce is not directly represented in the Australian workplace. It could be argued that Australian trade unions continue to perform a key labour market function through their role in bargaining, and the creation and enforcement of awards, contributing to determination of working conditions that apply to many Australian workers, irrespective of whether they are trade union members. Nonetheless, their role in relation to awards has become more limited in recent years; awards only provide a safety net and are confined to the 20 allowable matters (WRA s 89A). These matters only touch upon the information and consultation of employees to a limited extent. Thus, the decline of union representation poses a serious problem for the development of co-operative workplace relations in Australia.

Like unions, additional forms of employee information and consultation have an important role to play in the Australian industrial relations context. Some Australian companies have retained schemes of employee representation to achieve higher levels of productivity and performance, but empirical studies of workplace relations indicate that the level of joint decision-making in Australia is relatively underdeveloped (Morehead, et al, 1997). A recent review of joint consultation committees in federal certified agreements catalogued the problems pertaining to the features or characteristics of these bodies. The characteristics

\footnotetext{
${ }^{19}$ It is noteworthy that many European countries have developed more extensive participation obligations. For instance, in Germany and the Netherlands works councils have certain rights to make joint decisions with management. For present purposes we support the minimum standards developed at the European level. Once minimum standards are accepted in Australia, it may be that higher standards would be developed in the future. Invariably, these standards are a product of compromise between the various views of different industrial parties.
} 
included the composition of the committee, mode of appointment, frequency of meetings, topics discussed and powers of the committee. It is apparent that these features differ markedly from one committee to another, lack clarity in terms of the obligations expected of the parties, and fail to meet a range of the good practice criteria outlined in this paper. (Korman,S; JCC 2004). ${ }^{20}$ Furthermore, the lack of readily defined collective structures in non-unionised workplaces can mean that greater reliance is placed on management's ability to implement processes of change. This in turn may involve a considerable investment of management time and resources.

The absence of employee input into Australian corporate decision-making can be contrasted unfavourably with the superior representation and involvement of employees in Europe (Campling and Gollan, 1999: ch.7). These findings, together with the decline in union membership, have led to the development of the concept of an Australian employee 'representation gap'. One consequence of such a gap is obviously that employee voices are not heard. Another is that workplace-specific decisions are increasingly left to be dealt with by employers and managers. As we have commented above, this can lead to increased costs for management in consulting the workforce.

The Government could both assist these enterprises and address the perceived representation gap, by providing a legislative framework for employee information and consultation in Australia. The European experience with methods of consultation in the workplace does provide a useful model for the development of new methods of employee representation in Australia (Gollan and Patmore, 2003; Gollan, Markey and Ross, 2001). The Government could supplement the existing methods of workplace representation and negotiation in the $W R A$ by providing for employers and employees to form ongoing joint consultative committees based on a legislative model that draws on the $N D I C$ and $E W C D$. Such a model would be consistent with recent policy of the Australian Government to have workplace conditions determined as far as possible at the level of the workplace, and to involve employees in determining workplace conditions.

\footnotetext{
${ }^{20}$ See Wage Net, last accessed 8 June 2005 at $<$ http://www.wagenet.gov.au/WageNet/Search/Search.asp?Render=All $>$. These industries were chosen from the industry classifications provided by the Federal Government on its Wagenet database.
} 
It is important to emphasise the key conceptual difference that would underlie such a scheme. Drawing on the European experience would mean emphasising the importance of the provision of information, and consultation, quite separately from traditional collective bargaining, but in a way that is complementary to it. Such a scheme could be implemented in a way that would also complement both employee representation at the workplace through unions, and the individualised arrangements promoted by the current federal Government (Gollan and Hamberger, 2002). This would represent a significant development in Australia, where employee participation (through information and consultation) has generally been seen as an adjunct to the award process or to collective bargaining, or alternatively, as simply unnecessary.

Another key element of the European experience with workplace consultation is that it typically excludes pay from the topics for discussion within information and consultation committees (although where there is no union in the workplace, such committees in some countries may negotiate collective agreements). The removal of the key item of workplace conflict from the industrial equation assists as an incentive to begin dialogue, in an atmosphere that can become highly conducive to co-operative workplace relationships.

At the outset, the government could trial and promote a voluntary legislative scheme, or encourage participation in other ways, including tax breaks, or the introduction of a reporting requirement. If the scheme were to be voluntary, it would be hard to see any sustained opposition by employer groups, especially as there is support from all parts of the political spectrum for the development of such schemes of employee representation (Gollan and Hamberger, 2002; Combet, 2001). At the same time, however, it appears that a legislative framework would ultimately be required; the voluntary approach of leaving it to employers and employees to develop their own arrangements has not redressed the lack of clarity and current low levels of joint consultation in Australia.

To conclude, we believe that the Australian government should enact a new information and consultation procedure which would be in addition to the current federal enterprise bargaining process. The key features of the framework, such as topics to be discussed, the powers and composition of the committee, and mode of appointment of employee representatives, could draw upon the provisions of the NDIC and EWCD as well as good 
practice in Australia and Europe. To establish such a legislative framework we believe that it would be necessary to amend the WRA.

\section{Amending the WRA}

If the government were to introduce a legislative model it would be necessary to amend the $W R A$. We now consider how the EU partnership model might be fashioned to existing Australian legislative arrangements through changes to the awards system, enterprise bargaining, and Australian Workplace Agreements. ${ }^{21}$ Finally, we briefly revisit what would be constitutionally possible and how such a law would mesh with state laws.

As we have shown, it would be constitutionally possible to enact a legislative model of employee participation based upon the federal Corporations and Labour Powers. These powers provide fertile ground for the development of an Australian scheme which would operate in a similar manner to the EWCD and the NDIC. Should there be a conflict between the federal and state models, the federal law would prevail to the extent of inconsistency with the State law (Australian Constitution, s 109). However, as there is currently an absence of a general right for information and consultation at the state level it is unlikely that an inconsistency would arise. Thus a federal information and consultation committee could operate consistently with both Federal and State industrial relations laws. Alternatively the establishment of a Federal model may inspire state governments to develop their own new schemes of employee representation. This is to be welcomed given the limitations on the federal parliament's power to enact industrial relations laws. Such schemes could operate under state law in areas that cannot be regulated by the Australian parliament because of constitutional limitations on its powers.

\section{Awards}

To introduce partnership arrangements into awards it would be necessary to amend the $W R A$, given that such arrangements are not regarded as being allowable award matters (WRA

\footnotetext{
${ }^{21}$ The following description of amending the WRA draws from a helpful lecture by Colin Fenwick, Labour Relations Law, Melbourne Law School, December 2002.
} 
s 89A). ${ }^{22}$ While the Parliament can provide or withdraw legislative support for terms and conditions of employment it cannot directly regulate the conditions of employment in an award (Re Pacific Coal: Gleeson CJ: 359; Gummow and Hayne JJ: 418; Callinan J: 450) as the process of conciliation and arbitration must be recognisable as such (Re Pacific Coal, Kirby J: 437) Thus, the specifics of the terms and conditions of a standard information and consultation clause would have to be determined by the Commission acting as an independent body settling an industrial dispute in the public interest (Crichton \& Stewart, 2000: 66)

The Parliament could also encourage the parties (unions and employer organisations) who are engaged in an industrial dispute to agree on a standard information and consultation clause to be inserted into awards, subject to the Commission's approval. Because of the wording of the Federal Labour power, the Commission would have to either order conciliation or arbitrate the dispute in a test case (Crichton \& Stewart, 2000: 68). Crichton \& Stewart note that "it would appear that any system which facilitates private dispute resolution by recognising and enforcing collectively or individually negotiated agreements may only be validly enacted in reliance upon the industrial power if the disputes in question are otherwise subject to conciliation and arbitration" (Crichton \& Stewart, 2000: 68).

In addition, the government could encourage the parties to give effect to their agreements by asking the Commission to give consent awards under s 111(1)(b) of the WRA. While this is a rarely used provision it might provide a means for encouraging voluntary agreements. ${ }^{23}$ Employers and unions could also engage in over-award bargaining to create their own information and consultation procedures without any amendment to the $W R A$, but such an agreement would be unenforceable. Moreover, the Commission has emphasised that enterprise agreements are best made through certified agreements under Part VIB of the WRA.

\footnotetext{
${ }^{22}$ As discussed the AIRC deleted the general information procedures inserted by the TCR Case into awards because they did not fall within the scope of allowable award matters (WRA s 89A).

${ }^{23}$ The commission prefers certified agreements because Part VIB was purposely put into the WRA to facilitate the making and certifying of agreements and provides a more appropriate approach than the making of consent awards, which are intended to settle industrial disputes. See Review of Wage Fixing Principles 1994: 153-5; Re Review of Wage Fixing Principles 1993: 302-6.
} 


\section{Enterprise bargaining and certified agreements}

Enterprise bargaining provides a process by which a standard information and consultation procedure could be introduced into Australian workplaces. Such a procedure could be established through an agreement without legislative amendment, the agreement could be unregistered (which may not be enforceable) (Ryan v TCFUA [1996] 2 VR 235) or it could be certified as either a Corporations agreement (WRA Part VIB Division 2 ss 170LO \& 170LP) or a Disputes agreement (WRA Division 3, s 170LK). Disputes agreements are between a union and an employer and are supported by the Federal labour power (WRA ss 170LO \& 170LP). Corporate agreements may be made with either a union (WRA ss 170LJ \&170LL) or directly with a valid majority of employees (WRA s 170LK), and are supported by the Federal Corporations power. The parties are bound by a certified agreement in most circumstances (Generally WRA Div. 6 of Part VIB).

The scope of certified agreements are defined by the $W R A$. Partnership arrangements would fall within the statutory definition of such an agreement, which refers to "matters pertaining to the relationship between [the employer] and all persons ... whose employment is subject to the agreement' (WRA s 170LI). Despite the recent High Court decision in Electrolux Home Products Pty Ltd v Australian Workers Union (Electrolux), which more restrictively interpreted these words, it is hard to argue that this interpretation should exclude the establishment of information and consultation procedures because these so obviously pertain to the subject matter of the relationship between "employers and employees in their capacity as such" and employment agreements under the Act (Electrolux: Gleeson CJ: 54; McHugh J 66; Gummow, Hayne and Heydon JJ: 91).

Moreover, federal regulation of certified agreements facilitates the voluntarist approach of allowing the establishment of employee participation schemes in Australian enterprises. If the federal parliament is to introduce a legislative scheme of information and consultation into certified agreements it would be necessary to amend the WRA. The federal parliament could specify the employment conditions for information and consultation to be established under Corporate Agreements. Under the corporations power the federal parliament can directly regulate the conditions of employment in a certified agreement; and is not restricted in the kind of legislation it can enact as it is under the awards system. 
It is also important to note that the restrictive interpretation from the Electrolux decision is not an obstacle to the introduction of a legislative model because their Honours' reasoning is based on statutory interpretation and not on constitutional limitations on Federal powers (Electrolux: Gleeson CJ: 53-54; McHugh J: 71-72; Gummow, Hayne and Heydon JJ: 92).

\section{Australian Workplace Agreements}

A third method for introducing information and consultation procedures into Australian enterprises would be to include them in an Australian Workplace Agreement (AWA). These are not contracts of employment (WRA s $170 \mathrm{VF}(2)$, Fenwick, 2002), but are agreements negotiated between an individual employee and an employer, which are supported by regulation under a federal power such as the Corporations power of the Australian Constitution (WRA s 170VC). Information and consultation committees under an AWA can be formed without legislative amendment of the WRA. This is because AWAs cover matters that pertain to the relationship of employer and employee (WRA s $170 \mathrm{VF}(1))$. The restriction of allowable matters under the awards system does not apply to the making of an AWA.

To create a legislative model of an information and consultation procedure in an AWA, it would be necessary to amend the $W R A$. There would be no legal barrier to the creation of such a model since provisions already exist stipulating that certain conditions must be specified in AWAs, such as a prohibition against discrimination (WRA s 170VG(1)), and resolution of disputes (WRA s $170 \mathrm{VG}(3)$ ).

The model for an information and consultation procedure to be incorporated into either an AWA or certified agreement could be comprehensively specified in an appendix to the $W R A$. This would mean some provisions of the WRA would become unnecessary and could be repealed. For instance, the redundancy provisions of the WRA could be removed because they would be replaced by a more effective information and consultation procedure. Alternatively, a model could be integrated throughout the $W R A$ 's provisions by amending specific provisions in the legislation. For example, the freedom of association provisions of the WRA could be amended to provide formal legal protection for employee representatives from any form of victimisation or discrimination and to provide protection to employers for their confidential information (Gollan and Hamberger, 2002: 35). 
Thought would need to be given to how the procedural operation of a proposed information and consultation committee could be streamlined. For instance, would the committee be a party to the certification of an enterprise agreement, or would it be consulted in the drafting of an AWA. Hence, some procedural steps for a certified agreement under s 170LK of the WRA could be eliminated (Gollan and Hamberger, 2002: 35). Some changes could be made to the commencement date of AWAs and the cooling-off period (Gollan and Hamberger, 2002: 35).

In summary, the government's voluntary approach is supported by the current provisions of the WRA particularly in relation to enterprise bargaining. If the government were to introduce a legislative model it would be necessary to amend the WRA. Such a model could be introduced through the processes of creating awards, certifying agreements and negotiating AWAs. Yet each of these options provides a means to create a legislative model of employee representation.

\section{The Effectiveness of a Legislative Model}

While it is clearly possible to amend the $W R A$ to introduce a legally mandated scheme of employee participation it is necessary to consider the likely success of such a model. We now consider the effectiveness of creating such a model by exploring the application of EU laws in the Australian context. While there is wide-spread agreement that labour laws can be transferred from one legal system to another, opinions differ over the effectiveness of the transferability of such laws.

One useful approach in assessing the effectiveness of such a transfer has been developed by Gunther Teubner (Teubner, 1998: 17-27). He argues that the transferability of a foreign law depends upon the extent of the connection with other social processes such as the political, cultural and economic (Forsyth, 2005; Teubner, 1998: 19) ${ }^{24}$. According to Teubner, where the foreign law is "loosely coupled" with other social systems, the transfer is easier (Teubner, 1998: 19). However, resistance to transferability is higher where the law is "tightly coupled" or closely connected to other social processes. (Teubner,1998: 19). Where the law does not have the same level of connection in the recipient country it will become an "irritant in the new setting" (Forsyth, 2005; See Teubner 1998).

\footnotetext{
${ }^{24}$ The description of Teubner's approach draws upon a helpful lecture by Anthony Forsyth, 2005.
} 
We now apply Teubner's approach to assess the effectiveness of the transferability of the EU social partnership model to Australia. We therefore consider the degree of connection between the EU directives and the economic and industrial relations systems in Australia and Europe, and we highlight some key differences and similarities.

In our study we note that there are important differences between different European countries which will affect their usefulness as a comparator model for Australia. While works councils are well established institutions in Germany and the Netherlands, these institutions have only been recently introduced into the United Kingdom. The United Kingdom is a useful comparator for Australia as it is a common law country, with an adversarial industrial relations system and has been influenced by similar neo-liberal political policies.

\section{Changing the Workplace Culture}

A critical issue in the transferability of foreign laws is whether or not they can create effective changes in work culture. Partnership arrangements have been criticised as ineffective on the basis that they are both unclear and misleading.

\section{Partnership lacks clarity}

The transferability of these European-style laws will depend upon the clarity of social partnership arrangements. Partnership has been criticised as a confusing idea because it offers little in the way of direction. Debates have raged in the United Kingdom over the meaning of partnership, which has been described as 'all things to all people' (Hyman, 1997; Kelly, 1998; Kelly, 1999). There are a number of competing definitions. In the United Kingdom, it has been suggested that this lack of clarity is an obstacle in the dissemination and implementation of ideas of partnership (Involvement and Participation Association (IPA), 2002). However, the European model of social partnership is not a term without content. In our view this model is grounded in specific laws and directives, which provide coherence and definition to the concept in the United Kingdom and elsewhere. 


\section{Partnership is misleading}

Another criticism made of the 'partnership' idea is that it is misleading, and creates a false impression that there is an equality of bargaining power between employers and employees (Christodoulou, 2001; Glasbeek, 2002). It is further argued that even though it may be possible for the idea of partnership to be given more substantive meaning, without equal bargaining power it will not be possible to actually achieve a non-adversarial model of workplace democracy as is presupposed by partnership. Glasbeek argues that the law of employment can reinforce the inequality between employees and employers. The law clearly states that workers are not employers' partners, and are instead legally subordinate to employers. That which the employees sell - their bodies, intellect, skill etc. - are subjugated to the dictates of the employer. This creates a fundamental conflict between employees and employers such that the employment relationship is not treated as a partnership by law and cannot be a partnership in fact, no matter how co-operative employers and employees become within existing structures.

In our view, the mere idea of partnership may not be sufficient to change social consciousness and work practices. However, the EU directives outlined in this article usher in new legal arrangements, creating new legal rights and entitlements for employees and obligations on employers. They thus serve as a power-balancing function, seeking to redress some of the inequalities in the employment relationship that have been criticised. Moreover, the word 'social' qualifies the word 'partnership', and contributes to creating a new form of industrial consciousness.

\section{Free market versus social market economies}

One question is whether or not the creation of a general right to information and consultation under European law can only operate effectively in Europe but not in the Australian economy. It is important to consider the different types of economic systems and the nature of corporate governance in the different economies. It is argued that information and consultation arrangements along the lines of the EWCD and NDIC are incompatible with Australia's free market economy as opposed to the European social markets (Cameron, 2001). The legal regulation of corporate governance is apparently different in each 
jurisdiction (Forsyth, 2005). Companies are quasi public bodies that recognise stakeholder interests, including employees in continental corporations (Forsyth, 2005). Works councils do participate in the appointment of employee representatives on company boards in some European countries (See for example, the Civil Code of The Netherlands).

The legal regulation of corporate governance in Australia is based on a shareholder centred model. As a general rule employees do not have representation on company boards.

However, as Forsyth mentions there have been shifts in Australian corporate governance that may be of benefit to employee interests. Changes to corporate law in the wake of company collapses have attempted to protect workers' entitlements over the last few years (Forsyth; 2005; See for example Corporations Law Amendment (employee entitlements) Act 2000 (Cth)). However in our view, the arguments over the obstacles created by different legal regulations of corporate governance are somewhat misconceived. The legal obligations created by the NDIC and the $E W C D$ do not operate at the level of board management. Rather they operate at the level of the employment relationship. Therefore, the European partnership model as contained in EU directives can operate effectively regardless of which approach to corporate governance is adopted. While a shareholder primacy approach in relation to corporate governance continues to operate, it should not be a significant barrier to the introduction of an effective European style information and consultation system in Australia.

\section{Workplace co-operation and conflict}

A critical issue that arises in relation to the transferability of employment law is how effectively the law regulates workplace co-operation and conflict. It has been argued that EU partnership arrangements are incompatible with Australia's system of conflictual negotiations over wages and conditions (Cameron, 2001). We argue, however, that this view is incorrect because it fails to properly consider the potential of the co-operative elements of Australia's industrial relations system. The Australian system is not solely a conflictual system. While conflictual industrial relations are a significant part of the system, the system does not per se exclude co-operative work arrangements. Indeed these are an important part of the system too. Co-operative workplace arrangements exist in the form of conflict resolution through the process of conciliation and arbitration at the federal and state levels (Forsyth, 2005). As we have shown, Australia has developed systems of co-operative industrial relations in the past. Institutions for developing economic and labour policy in the form of the Accord were 
created at the national level of government, and institutions such as joint consultative committees and consultation over redundancies have been created at the company level (Forsyth, 2005). Therefore the Australian industrial relations system can in fact accommodate co-operative workplace arrangements which might include new employee rights to information and consultation in the workplace.

It has also been argued that the Australian process of conflictual collective bargaining could "taint" the proposed consultative procedures, which would also operate at the level of the enterprise (Forsyth, 2005). The European social partnership model avoids this problem by separating worker representation functions, allowing unions to conduct collective bargaining, and creating separate bodies such as works councils through which consultation occurs (Forsyth, 2005). Importantly, the European social partnership model removes the contentious issue of pay.

One assumption of the critics' view of the European social partnership model, is that it is founded upon a co-operative workplace relationship. In our view, the social partnership model may have a range of consequences for the management of co-operation and conflict in industrial relations. One plausible view is that the social partnership models indeed can create a new form of employee cooperation, minimising industrial conflict. In the United Kingdom, it has been suggested that 'social partnership' is based on a series of general principles: 'a joint commitment to the success of the enterprise, to building trust and mutual recognition of the legitimate role of employer and employee representatives' (IPA, 1992). This partnership model is said to replace an environment of adversarial bargaining and reactive conflict for consultation and co-operation, based on models developed in Germany ${ }^{25}$ and Scandinavian countries (Ackers, et al, 2002; Gospel and Willman, 2002).

An alternative view is that the social partnership model may cohabit with conflictual models of industrial relations. It is argued that partnership does not erode the potential conflict that may exist between employers and employees over wages and conditions mediated through collective bargaining. For instance, the $E W C D$ does not deal with the traditional function of collective bargaining. In this context 'social partnership may offer a new vision of the place

\footnotetext{
${ }^{25}$ Germany has multi-channel representation - collective bargaining outside the firm and legally-based joint consultation at the workplace and enterprise level, along with employee representation on the supervisory board of companies (Gospel and Willman, 2002).
} 
of unions in participation arrangements', by engaging in new co-operative work arrangements and still continuing their function to engage in conflictual collective bargaining.

It must also be acknowledged that under this model 'a variety of outcomes are possible, ranging from compatibility or indeed synergy, through to tension and competition between management and union representatives to secure influence' (Ackers, et al, 2002). In summary, in our view information and consultation procedures introduce a process of social dialogue which foster co-operative tendencies, but allow for a range of co-operative and conflictual responses in the workplace.

\section{Social partners}

The management of workplace conflict and co-operation will affect the interest of employers and unions in more specific ways. Both employers and employees are regarded as social partners, and the extent to which they are willing to take on these roles will depend on how the information and consultation procedures affect their interests. Partnership aims to minimise the costs and maximise the benefits for both parties. Employers can seek cooperation in maximising efficiency and flexibility, whilst employees can seek greater job security. Partnership arrangements are meant to assure unions that they will not be marginalised from workplaces and instil confidence in employers that they will be able to manage their business effectively. We now consider the implications of the partnership model for Australian managers and unions in more depth.

\section{Implications for Trade Unions}

In recent years there has been a debate within the Australian union movement over whether unions should support the introduction of new forms of employee representation. There seems to be a gradual shift in favour of supporting these new structures. Interestingly, a similar shift in support by trade unions for such mechanisms occurred in the United Kingdom. The UK peak union body, the Trade Union Council, now advocates partnership arrangements. ${ }^{26}$ While advocates in Australia may not see the introduction of alternative consultation arrangements as a means to significantly redress the decline in Union membership (Forsyth, 2005) they see other important benefits of such mechanisms. As Greg

\footnotetext{
${ }^{26} \mathrm{http}: / /$ www.tuc.org.uk/partnership/index.cfm
} 
Combet points out, the topics for discussion by European-style works councils highlight the deprivation of entitlements of Australian employees. As he notes, Australia is now decades behind EU developments in consultation rights (Combett, 2001). His support for such structures is not unqualified. As Combett warns, he would not support structures that negate, undermine or diminish the ability of unions to organise, represent and collectively bargain on behalf of their members (Combett, 2001).

Some unionists in Australia may fear that such mechanisms might potentially marginalise unions, 'threatening their traditional role of defending and advancing worker rights' (Ackers, et al, 2002: 4). Kelly argues that employee involvement based on the creation of consultative arrangements, such as works councils, means that employers can secure workforce consent to corporate goals such as profit maximisation and cost reduction without consultations with a trade union (Kelly, 1999).

However, it is argued that such a view is not applicable to the European social partnership model because unions are regarded as social partners who would be expected to participate in works council deliberations. The European (and EU) concept of social partnership is based on social dialogue between employers and employees, through representative bodies, notably trade unions and works councils (Ackers, et al, 2002). For instance the EWCD combines both of these ideas by envisaging a role for unions as employee representatives on works councils.

However, the way in which unions are to perform these functions is not straight forward. This is because selection of employee representatives under the EWCD and NDIC may be either by election or appointment. The provision of alternative procedures for appointments (appointment or election) under the EU directives was designed to allow for appointments based on union membership in some European countries. However, in the UK the EWCD and $N D I C$ do not provide any automatic participatory rights for union representatives who must stand for election alongside other non-union representatives. Potentially, such arrangements may operate with, against, or in the absence of union structures (Gollan, 2003b). Nonetheless, the use of the Directives to exclude unions is blunted because there is no prohibition on union members standing for election. In the UK and Australia, unions may be seen to be in an advantageous position, because they are most likely to be able to find people to act as employee representatives. If Australia adopts the social partnership model it is not likely to undermine the activities of trade unions. 
Trade unionists are well placed to act as information and consultative representatives in Australia. While they may need some training to be effective employee information and consultation representatives it is also likely that they will be well placed to perform this function based on the experience they have gained through their collective bargaining activities. They would be familiar with some of the processes associated with works councils such as negotiations over contractual relations and discussion of changes in workplace organisation, and would be familiar with electoral processes.

Finally, unions should be comforted by Kelly's suggestion that the 'power resources wielded by workers, through unions and works councils, mean that 'social partnership' may involve a mutual accommodation of interests rather than an imposition of the employers' interests' (Kelly, 1999: 3).

\section{Implications for management}

Cameron argues that the current attitudes and cultures of employers in Australia stand as a major barrier to the establishment of effective representative works councils (Cameron, 2001). Opposition to such processes may arise because managers may fear that partnership arrangements will remove their 'right to manage' or their right to exercise their managerial prerogative. In our view this fear is misconceived. The framework of consultation does not remove managerial prerogative since the final decision rests with management. Alternatively, management may fear that employee information and consultation rights would restrict the exercise of managerial prerogative, that they will not be able to make prompt decisions, and that there will have to be an accommodation of interests between works councils representatives and managers. If a model based on the EU Directives was adopted in Australia the topics for consultation would need to be specified, curbing both the power of unions and managers. In our view the accommodation of interests strengthens rather than weakens management decision-making. Evidence from Europe suggests that the process of consultation does not cause undue delays in managerial decision-making and moreover consultation processes refine and reshape managerial decision-making. 
To facilitate the process of consultation, social partnership is not only built on high trust, cooperation and compromise, but as a basic assumption, it is built on 'social relations' between the employees through their representatives, employers and the state. This interaction shapes and influences their expectations and strategies in achieving their aims through the bargaining process (Frege, 2002).

Significantly, this process has positive benefits for organisational outcomes and competitiveness (Collins, 2003.b: 2) Collins argues that EU regulation through social partnership initiatives support and encourage those types of employment relations which are highly productive (Collins.b, 2003: 5). In particular, he argues that partnership institutions 'provide an institutional framework for encouraging disclosure of information and collaboration between workers and management to direct the business towards the most profitable avenues'. Significantly, Collins goes on to suggest:

These highly productive employment relationships are identified as using highly skilled workers, who co-operate together in a knowledge-based economy to create innovative products in highly efficient ways. Regulating for competitiveness involves the search for institutional frameworks that facilitate the development and stability of these flexible kinds of employment relations. [For example] The lack of employment security in businesses that are undergoing a continuous process of adaptation clearly creates the risk that employees will not co-operate with innovation and try to place obstructions in the way of business reorganisation. One way to counter this concern of the workforce is to ensure that they are informed at all times of business plans or work organisation plans, and that they are consulted about how best to handle change (Collins, 2003.b: 5-6).

Collins also explains how the legal rules based on partnerships create high trust relationships leading to competitive economic outcomes:

Effective co-operation requires ... the building of trust and the disclosure of information on both sides, and partnership institutions can contribute to this goal. Competitiveness also supports legal rules that build trust between the parties in other ways, so that they will be willing to accept flexibility in the terms 
of the arrangement in return for the safeguards provided or induced by the law (Collins. 2003b: 5).

The EU information and consultation directives are also regarded as a vital and positive response to the economic effects of globalisation. The directives are based on the principle that employers and employees should take the lead in modernising the workplace and the workforce. The EU's representative consultative arrangements represent a non-protectionist response to intensified international competition, seeking to enhance the performance of firms through improved co-operation between employees and management, and permitting continuous restructuring of the production process (Muller-Jentsch, 1995: $346 \mathrm{fn} 20$ ).

In discussing the $E W C D$, Padraig Flynn, the former European Commissioner with responsibility for Employment and Social Affairs, drew two conclusions from European experience regarding the process of restructuring:

[First,] that constant industrial change and corporate restructuring is an inevitable part of remaining competitive in the world. The second is that, if this constant industrial change and corporate restructuring is to meet its objective - if it is to be a positive factor in our competitiveness - then it needs to engage the workforce, as an integral and as a formal part of that process (Flynn, 1999).

It could be argued that like Europe, Australian firms are subject to the economic forces of globalisation and the need to remain competitive. Hence, partnership arrangements seem to offer significant potential for improving economic performance of Australian firms too.

\section{Implications for the government}

Governments also have a role to play in promoting partnership arrangements. Critics of partnership arrangements argue that the current government's attitudes are opposed to the establishment of effective representative works councils (Cameron, 2001). It is also noted that the role that unions should play is contested in Australian society (Forsyth, 2005). The critics' argument seems to assume that the attitudes of governments in Australia are immutable and unchanging. However, previous Australian governments have promoted more consultative industrial relations such as the Accord. In fact, EU partnerships based on the 
directives are designed to change and improve information and consultation procedures, and have done so in many cases.

Governments in Australia may find promotion of consultation at work attractive for many reasons. New forms of employee representation could harness the strength of employee knowledge and involvement to also help Australia confront important socio-economic problems. By creating a legislative model for information and consultation mechanisms, the Government could work to address key labour market problems by setting the agenda at a national (macro) level, while allowing implementation that best suits workers and managers at the enterprise (micro) level.

It could do so by establishing the key topics for discussion within information and consultation committees so as to address fundamental economic problems. These could include:

- Employability and skills training - to help manage the chronic skills shortages facing Australia;

- Finding better ways to integrate casual and permanent employees;

- Introduction of technological change - to enhance productivity;

- Managing acquisitions, mergers and redundancies - to better address the issue of job security;

- Discussing working hours - as a means of managing the work-life balance; and

- Considering flexible work practices to enhance efficient work outcomes.

The list of topics need only be framed in very general terms. Consistent with recent government policy, such a policy would not direct employers and employees as to outcomes. Rather, it would bring the parties together to discuss critical labour market problems, to find innovative solutions to suit each enterprise.

The logic of partnership arrangements provides guidance for their adoption. Working with others for the achievement of common purposes needs to be promoted at all levels. A legislative model establishing information and consultation procedures for Australia could be introduced therefore by the Australian government sitting down with peak, union, and employer organisations. This process would enable the expertise of all the organisations to 
contribute to developing a model which would effectively operate in the Australian labour market. A similar process was embarked upon by the UK Government in drafting the regulations for the introduction of the NDIC (Hewitt, 2003: Preface, DTI). As Patricia Hewitt explains, this was the first time the UK government had discussed the implementation of the European social legislation with peak employment bodies and it regarded the process as an 'interesting and successful experience' (Hewitt, 2003: Preface, DTI,). Given the experience of the Hawke government of consulting peak bodies, it is likely that the development of these kinds of partnership arrangements could be successfully introduced in Australia.

To evaluate the likely success of the adoption of EU partnership laws and arrangements in Australia, it is necessary to assess the similarities and differences in the operation of the IR and economic systems in each jurisdiction (Forsyth, 2005; Teubner, 1998). Australia's conflictual industrial relations systems may be a significant difference to the systems in some EU countries. The difference in corporate governance in Australia and Europe may not be a significant barrier since EU information and consultation directives do not operate at this level; rather they regulate employment relationships. Despite these differences there are important similarities which bode well for the adoption of such partnership arrangements in Australia. Firms in both Europe and Australia are both subject to the same economic pressures of globalisation and competitiveness. Trade unions have begun to look more favourably on the need to improve consultation rights, and Australian labour laws have continued to foster some limited but important consultative arrangements.

\section{Conclusion}

While the current focus on enterprise bargaining in the workplace might encourage us to think about new information and consultation mechanisms at work, there are no legislative provisions imminent. The voluntary approach has, however, failed to create a generally available right to information and consultation at work. We have reviewed European models of employee representation and consultation in the workplace with particular attention paid to the social partnership model of employee representation. We conclude that there are a number of lessons to be learnt from the European system of social partnership, and European experience suggests that these models may be useful in the Australian context. 
However, it must be recognised that under the EU information and consultation directives, the new co-operative tendencies do not fully eliminate the adversarial and conflict element in organisations, but channel it instead. As such, the patterns of tensions have shifted due to the changing expectations of employees and the interpretation of these expectations by their representatives. Such structures of employee consultation and involvement enable employees and employers to assemble in politico-economic forums, within which more democratic access is granted. This enables a richer process of consultation and employee involvement with associated positive social and economic outcomes.

It could be argued that increased support for these institutions is recognition that the creation of economic value is an essentially social process, and that organisational sustainability depends on legitimate social governance. As the above review demonstrates, perhaps employers, unions and governments should recognise that the time has come for new institutions to create a new type of participative, productive and democratic workplace in Australia. 


\section{References}

Australian Constitution.

Ackers, P., Marchington, A., Wilkinson, A., and Dundon, T. (2002), 'Partnership and voice, with or without trade unions: Changing British management approaches to participation', Working Paper, Loughborough University.

Appelbaum, E., Batt, R., Leana, C. (2003), 'Social capital at work', Perspectives on Work, vol.7, no.1, pp.7-9.

Application for order giving effect to Article 13 of the Termination of Employment Convention, Sydney, 7 AUGUST 2002

Australian Bureau of Statistics (2001), 6310.0 Employee Earnings, Benefits and Trade Union Membership, Canberra.

Australian Bureau of Statistics (2002), 6310.0 Employee Earnings, Benefits and Trade Union Membership, Canberra.

Australian Bureau of Statistics (2004), 6105.0 Australian Labour Market Statistics, Canberra.

Australian Centre for Industrial Relations Research and Training (ACIRRT) (2003) http://www.acirrt.com/research/default.htm.

Australian Federal Government, Industrial Relations Act 1988, Canberra: Australian Government Publishing Service.

Australian Federal Government, Industrial Relations Amendment Act 1993, Canberra: Australian Government Publishing Service.

Australian Federal Government, Corporations Law Amendment (employee entitlements) Act 2000 .

Australian Federal Government, Industrial Relations Reform Act 1993, Canberra: Australian Government Publishing Service. ('The Reform Act')

Australian Federal Government, Workplace Relations Act 1996, Canberra: Australian Government Publishing Service. (WRA).

Australian Federal Government, Workplace Relations and Other Legislation Amendment Bill 1996, Canberra: Australian Government Publishing Service.

Barnard, C. (1999), 'The changing shape of worker representation in the United Kingdom: the influence of European Community law', Journal of Labour Law, vol. 12, no. 1.

Bellace, J. (1997), 'The European Works Council Directive: transnational information and consultation in the European Union', Comparative Labour Law, vol. 18, no. 325. 
Brown, R (1992) Commonwealth Parliamentary Debates, House of Representatives, 24 June, 3793 (Robert Brown, Minister for Land Transport).

Burns, P. (2000), 'The Silent Stakeholders: Reforming Workforce Consultation Law', Policy Paper, The Industrial Society, London.

Cameron, D. (2001), 'The Representation Gap in Australia', Paper presented at Works Councils in the Australia Context: A Public Seminar and Discussion for Participants in the Australian Labour Movement, Melbourne.

Campling, J. and Gollan, P. (1999), Bargained Out: Negotiating without unions in Australia, The Federation Press, Sydney.

CCH (1998), Australian Enterprise Bargaining Update, no.22, March.

Civil Code, The Netherlands

Christodoulou, C. (2001), 'The shopfloor, united', Workers Online, 15 June, Issue no. 99, http://workers.labor.net.au/99/c historicalfeature work.html.

Coleman, J. (1988), 'Social capital in the creation of human capital', American Journal of Sociology, vol.94, supplement, pp. 95-121.

Collins, H. (2003 a), 'Partnership at Work', Presentation at the Melbourne Law School, Wednesday, 12 March, 2003.

Collins, H. (2003 b), 'The Evolving Direction of European Labour Law: Social Inclusion, Competitiveness and Citizenship', Paper presented at the Annual Labour Law Conference Rethinking the Law of Work: Perspectives on the Future Shape of Employment Regulation, 4 April, Sydney.

Combet, G. (2001), 'Employee Consultation in an Australian Context: The Works Council Debate', Speech presented at the Australian Works Councils Seminar, RMIT, 9 April, Melbourne.

Conference on the Practical Application of the European Works Council Directive (1999), Brussels, 28-30 April 1999, organised by the ETUC, UNICE and CEEP (supported by DG5).

Cooney, Sean, Tim Lindsey, Richard Mitchell, and Ying Zhu. (2002), Law and labour market regulation in East Asia, Routledge, London.

Cook, (1992), Commonwealth Parliamentary Debates, Senate, 7 May 1992, 2517 (Senator Cook, Minister for Industrial Relations).

Creighton B., and Stewart A. (2000), Labour Law: An Introduction, The Federation Press, Annandale.

Dabscheck, B. (1995), The Struggle for Australian Industrial Relations, Oxford University Press, Melbourne. 
Davis, E. and Lansbury, R. (1999), 'Consultation and employee participation in Australian workplaces: 1986-1995', in Davis, E. and Lansbury, R. (eds), Managing Together: Consultation and Participation in the Workplace, Longman, Melbourne, pp. 1-24.

Department of Employment and Industrial Relations ('DEIR') (1986), Industrial Democracy and Employee Participation: A Policy Discussion Paper, Australian Government Publishing Service.

Department of Trade and Industry (2002), High Performance Workplaces: The Role of Employee Involvement in a Modern Economy: A Discussion Paper, Green Paper, London.

Department of Trade and Industry (2003), High Performance Workplaces - Informing and Consulting Employees, Consultation Paper, London.

European Commission (1998), Commission adopts a proposal for a Directive on information and consultation of employees, 11 November, Brussels (IP/98/981).

Agreement on Social Policy attached to the Protocol (No 14) on Social Policy annexed to the Treaty establishing the European Community

European Parliament and Council (1994), 'European Works Council', Council Directive 94/45, 1994 OJ (L 254).

European Parliament and Council (1997), 'European Works Council', Council Directive 97/74, 1998 OJ (L 010).

European Parliament and Council (2002), 'A General Framework for Informing and Consulting Employees', Council Directive 2002/14/EC, 2002 OJ (L 080). ('NDIC').

European Works Councils: Toward More Influence, Report from the Conference in Aarhus, 25 - 26 November, 2002.

Fishman, N. (1995), 'TUC Consultative Document: Collective Representation at Work Practical Political Considerations', Unpublished, London.

Fenwick, Colin. Lecture: Labour Relations Law, Melbourne Law School, December 2002.

Flynn, P. (1999), 'European Works Councils: Practices and Development', Speech by the European Commissioner with responsibility for Employment and Social Affairs, Brussels, 28 April.

Forsyth, A (2002), "Giving Teeth to the Statutory Obligation to Consult over Redundancies", 15 Australian Journal of Labour Law No 2.

Forsyth, Anthony. PhD Work-in-Progress seminar, Monday 10 January 2005, Melbourne Law School, Carlton.

Freeman, R.B. and J.L. Medoff (1984), What Do Unions Do?, Basic Books, New York. 
Frege, C. (2002), 'A critical assessment of the theoretical and empirical research on German Works Councils', British Journal of Industrial Relations, vol. 40, no. 22., pp.221-248.

Gardner, M. and Palmer, G. (1997), Employment Relations: Industrial Relations and Human Resource Management in Australia, $2^{\text {nd }}$ ed, Macmillan, Melbourne.

Glasbeek, H. (2002), 'Beware of snake oil merchants — whoever they are! Partners at work', Unpublished Discussion Paper, Melbourne.

Gollan, P. (2000), 'Non-union forms of employee representation in the United Kingdom and Australia' in Kaufman, B.E. and D.G. Taras, (eds.), Non-union Employee Representation: History, Contemporary Practice, and Policy (Issues in Work and Human Resources), M.E. Sharpe, Armonk, New York, pp. 410-449.

Gollan, P. (2001), 'Tunnel vision: non-union employee representation', Employee Relations, vol. 23 , no. 4 , pp. $376-400$.

Gollan, P. (2002), 'Restoring faith after the demise of unions', Australian Financial Review, 26 April, p. 10 (Review).

Gollan, P. (2003a), 'Faces of non-union representation in the UK - Management strategies, processes and practice', Paper presented at the Special Seminar - New Forms of Organisation, Partnership and Interest Representation, International Industrial Relations Association World Congress, Berlin, 8-12 September, 2003.

Gollan, P. (2003b), 'Seduction without the love - The challenge for partnership', People Management, 11 September, London.

Gollan, P. (2003c), 'Great expectations - NER and the challenge for union and employer partnership', LSE Discussion paper, Department of Industrial Relations, London School of Economics.

Gollan, P. (2005), 'Representative Voice - The interplay between non-union and union representation arrangements at Eurotunnel' Advances in Industrial and Labor Relations, 2005, Vol 14. (forthcoming).

Gollan, P. and Hamberger, J. (2002), 'Enterprise-based Employee Representation in Australia - Employer Strategies and Future Options' in P Gollan, R Markey and I Ross (eds), Works Council in Australia - Future Prospects and Possibilities (eds.), Federation Press, Sydney.

Gollan, P. and Patmore, G. (2003), Partnership at Work: the Challenge of Employee Democracy, Labor Essays 2003 (eds). Pluto Press, Sydney.

Gollan, P., Markey, R. and Ross, I. (2001), Additional forms of employee representation in Australia, ACIRRT, Working Paper 64, University of Sydney.

Gospel, H. and Willman, P. (2002), 'The right to know: Disclosure of information for collective bargaining and joint consultation in Germany, France, and Great Britain', Discussion Paper No. 453, Centre for Economic Performance, London School of Economics. 
Gospel, H. and Willman, P. (2003), 'The Coming of Workplace Information Sharing and Consultation: What It Means for Employee Representation in Britain', Perspectives on Work, vol.7, no.1, pp. 38-39.

Hyman, R. (1997), 'The Future of Employee Representation', British Journal of Industrial Relations, vol. 35, no. 3, pp. 309-336.

Involvement and Participation Association (1992), Towards Industrial Partnership: A New Approach to Relations at Work, IPA, London.

Involvement and Participation Association (2002), 'Definitions of partnership', 25 September, http://www.partnership-at-work.com/pardefs.html

Kelly, J. (1996), 'Works Councils: Union advance or marginalisation?' in Aileen McColgan, ed., The Future of Labour Law, Mansell, London.

Kelly, J. (1998), Rethinking Industrial Relations: Mobilisation, Collectivism and Long Waves, Routledge, London.

Kelly, J. (1999), 'British Social Partnership agreements: who wins, who loses?', Draft paper presented Industrial Relations Department, London School of Economics, 4 June.

Knudsen, H. and Markey, R. (2002), 'Works Councils: Lessons from Europe for Australia' in Gollan, P., Markey, R. and Ross, I. (eds.), Works Councils in Australia: Future Prospects and Possibilities, The Federation Press, Annandale, pp.102-128.

Kochan, T.A., Katz., H.C. and McKersie, R.B. (1986), The Transformation of American Industrial Relations, Basic Books, New York.

Korman, S. (2004) JCC, Student Undergraduate Research Essay 2004.

Kotthoff, H. (1981), Betriebsräte und betriebliche Herrschaft: eine Typologie von Partizipationsmustern im Industriebetrieb, Campus, Frankfurt.

Leana, C. and Van Buren, H. (1999), 'Organizational social capital and employment practices', Academy of Management Review, vol.24, no.3, pp. 538-555.

Liberal-National Party Coalition, (1996), The Coalition Industrial Relations Policy, 'Better Pay for Better Work', Canberra.

Lloyd, C. (1999), 'What do employee councils do? Representation in non-union firms', Paper presented at British Universities Industrial Relations Association (BUIRA) Conference, De Montfort University, 1-3 July.

Markey, R. (1987), 'Neo-corporatism and technological change in Australia: an international perspective', New Technology, Work and Employment, vol. 2, no. 2, pp. 142-53.

Markey, R. and Regular, R. (1997), 'Consultative committees in the Australian steel industry' in Markey, R. and Monat, J. (eds), Innovation and Employee Participation through Works Councils: International Case Studies, Avebury, Aldershot. 
McCallum, R. "Crafting a New Collective Labour Law for Australia”. Journal of Industrial Relations 39 (3) September 1997 : 405-422.

McCallum , R. and Patmore, G. (2002), 'Works Council and Labour Law', Gollan, P., Markey, R. and Ross, I. (eds.), Works Council in Australia - Future Prospects and Possibilities, The Federation Press, Annandale.

Mitchell, R., Naughton, R. and Sorensen, R. (1997), 'The law and employee participation Evidence from the federal enterprise agreements process', The Journal of Industrial Relations, vol. 39, no. 2, pp. 196-217.

Morehead, A., Steele, M., Alexander, M., Stephen, K. and Duffin, L. (1997), Change at Work: The 1995 Australian Workplace Industrial Relations Survey (AWIRS 95), Longman, Melbourne.

Muller-Jentsch, W. (1995), 'Germany: From collective voice to co-management' in Rogers, J. and Streeck, W. (eds.), Work Councils: Consultation, Representation, and Cooperation in Industrial Relations, University of Chicago Press, Chicago and London.

New South Wales Government, Industrial Relations Act 1991, Sydney.

New South Wales Government, Occupational Health and Safety Act 2000, Sydney.

Patmore, G. (1999), 'Creating the participatory society: workplace democracy for Australia', Patmore, G. and Glover, D. (eds.), New Voices for Social Democracy: Labor Essays 19992000, Pluto Press, Sydney.

Patmore, G. (2001), 'A new light on an old hill, industrial democracy for Australia: towards a new form of employee representation in the workplace', Arena, June-July, pp. 45-48.

Pragnell, B and P Ronfeldt. (1994), 'Redundancy Under Enterprise Bargaining and New Federal Laws' in R McCallum et al (Eds), Employment Security, The Federation Press, Sydney, pp 115-37.

Sako, M. (1998), 'The nature and impact of employee 'voice' in the European car components industry’, Human Resource Management Journal, vol. 9, no. 1, pp. 5-13.

Sherry, (1993), Commonwealth Parliamentary Debates, Senate, 24 November, 3579 (Senator Sherry, Parliamentary Secretary to the Minister for Primary Industries and Energy).

The Information and Consultation of Employees Regulations 2004 UK Statutory Instrument No. 3426. $(I \& C E R)$.

The Transnational Information and Consultation of Employees Regulations 1999 UK Statutory Instrument 1999 No. 3323. ('TI\&CE Regs 1999').

Teubner, Gunther. (1998), 'Legal Irritants: Good Faith in British Law or How Unifying Law Ends Up in New Divergences', Modern Law Review vol. 61 (1), 11-32. 
United Kingdom Government, Draft Regulations, 'The Information and Consultation of Employees Regulations 2004' under s 41 of the Employment Relations Act.

Victorian Government, Occupational Health and Safety Act 1995, Melbourne.

Walton, R. E. (1985), 'From control to commitment in the workplace', Harvard Business Review, March-April, vol. 64, no. 3, pp. 77-84.

Cases

Amalgamated Metal Workers Union of Australia v Shell Refining (Australia) Pty Ltd (1993) 36 AILR 185.

ALHMWUv Rydges Australia Pty Ltd (2001) 50 AILR 4-471(77).

Communications, Electrical, Electronic, Energy, Information, Postal, Plumbing and Allied Services Union of Australia v Vodafone Network Pty Ltd PR 911257 (Unreported, Australian Industrial Relations Commission, Commissioner Smith, 14 November 2001). ('Vodafone')

Communications, Electrical, Electronic, Energy, Information, Postal, Plumbing and Allied Services Union of Australia v Optus Administration Pty Limited PR 912122 (unreported, Australian Industrial Relations Commission, Commissioner Smith, $4^{\text {th }}$ December 2001). ('Optus')

Electrolux Home Products Pty Ltd v Australian Workers Union (2004) 133 IR 49. ('Electrolux')

Finance Sector Union of Australia v. Commonwealth Bank of Australia Employees- Award 1999 PR921049 (unreported, Australian Industrial Relations Commission, Commissioner Lawson, $7^{\text {th }}$ August 2002). ('Commonwealth Bank 1')

Finance Sector Union of Australia v. Commonwealth Bank of Australia, PR921470 (2002) 116 IR 391. ('Commonwealth Bank 2')

National Wage Case April 1991 (1991) 36 IR 120.

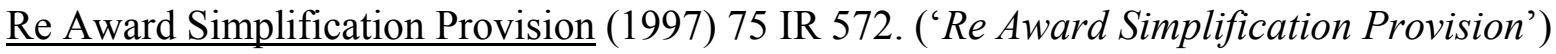

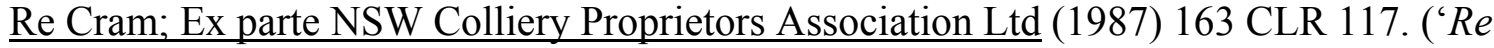
Cram')

$\underline{\text { Re Pacific Coal Pty Limited; Ex parte Construction, Forestry, Mining and Energy Union }}$ (2000) 203 CLR 346. ('Re Pacific Coal').

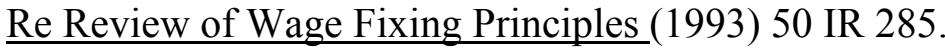

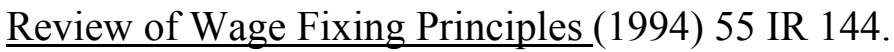

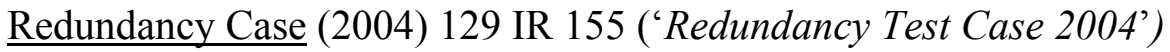

Ryan v TCFUA [1996] 2 VR 235. 
Termination, Change and Redundancy Case (1984) 26 AILR 256; (1984) 294 CAR 175;

(1984) 8 IR 34. ('TCR Case 1984')

Termination, Change and Redundancy Case (1985) 27 AILR 1; (1984) 295 CAR 673; (1984)

9 IR 115. ('TCR Case 1985')

Victoria v Commonwealth (1996) 187 CLR 416. ('Industrial Relations Act Case') 